\title{
A novel dietary supplement containing multiple phytochemicals and vitamins elevates hepatorenal and cardiac antioxidant enzymes in the absence of significant serum chemistry and genomic changes
}

\author{
Elida Bulku, Daniel Zinkovsky, ${ }^{1}$ Payal Patel, ${ }^{1}$ Vishal Javia, ${ }^{1}$ Tejas Lahoti, Inna Khodos, Sidney J. Stohs² and Sidhartha D. Ray',2,* \\ 'Molecular Toxicology Laboratories; Division of Pharmaceutical Sciences; A \& M Schwartz College of Pharmacy and Health Sciences; Long Island University; Brooklyn, NY USA; \\ ${ }^{2}$ Creighton University School of Pharmacy and Allied Health Professions; Omaha, NE USA
}

Key words: antioxidant enzymes, sage extract, oolong tea extract, guarana extract, oxidative stress, liver, kidney, heart, genomic integrity, Fisher 344 rats

\begin{abstract}
A novel dietary supplement composed of three well-known phytochemicals, namely, Salvia officinalis (sage) extract, Camellia sinensis (oolong tea) extract, and Paullinia cupana (guarana) extract, and two prominent vitamins (thiamine and niacin) was designed to provide nutritional support by enhancing metabolism and maintaining healthy weight and energy. The present study evaluated the safety of this dietary supplement (STG; S, sage; T, tea; G, guarana) and assessed changes in target organ antioxidant enzymes (liver, kidneys and heart), serum chemistry profiles and organ histopathology in Fisher 344 rats. Adult male and female Fisher 344 rats were fed control (no STG) or STG containing ( $1 \mathrm{X}$ and 7X, $1 \mathrm{X}=$ daily human dose) diets and sacrificed after 2 and 4 months. Serum chemistry analysis and histopathological examination of three vital target organs disclosed no adverse influence on protein, lipid and carbohydrate profiles, genomic integrity of the liver and/or the tissue architecture. However, analysis of the most important antioxidant components in the liver, kidney and heart homogenates revealed a dramatic increase in total glutathione concentrations, glutathione peroxidase and superoxide dismutase enzyme activities. Concomitantly, oxidative stress levels (malondialdehyde accumulation) in these three organs were less than control. Organ specific serum markers (ALT/AST for the liver; CPK/AST/LDH for the heart; BUN/ creatinine for kidneys) and the genomic integrity disclosed no STG-induced alteration. Some of the serum components (lipid and protein) showed insignificant changes. Overall, STG-exposed rats were more active, and the results suggest that STG exposure produces normal serum chemistry coupled with elevated antioxidant capacity in rats fed up to seven times the normal human dose and does not adversely influence any of the vital target organs. Additionally, this study reiterates the potential benefits of exposure to a pharmacologically relevant combination of phytochemicals compared to a single phytochemical entity.
\end{abstract}

\section{Introduction}

A dramatic increase has occurred in recent years in the popularity of phytochemicals, nutraceuticals and other dietary products to support health and wellness. A majority of adults in the US now regularly use products, commonly referred to as supplements, containing these ingredients in order to maintain wellness or treat an illness. In the past, much of the information supporting the efficacy of natural products was anecdotal. However, high quality, hypothesis-driven studies in animals and humans as well as in in vitro systems have greatly contributed to our knowledge of the safety and efficacy of these products and an understanding of the underlying mechanisms. As a consequence, an ever increasing number of phytochemicals are being recognized not only for their abilities to prevent disease states and support wellness (chemoprotective properties), but also to effectively treat various diseases. ${ }^{1-4}$

More than 5,000 phytochemicals with diverse structures and functions have been identified to date. Each phytochemical has a unique structure and has the potential to alter cellular functions in a specialized manner without jeopardizing the macromolecular conformations, although their modus-operandi can differ in different research models. In the last two decades, our laboratories have conducted mechanistic experiments investigating the anticancer, ${ }^{4,5}$ anti-toxic, ${ }^{6-9}$ anti-obese, ${ }^{10}$ anti-diabetic ${ }^{11}$ and anti-aging properties ${ }^{12-14}$ of a number of phytochemicals and several uniquely 
designed complex mixtures of phytochemicals, ${ }^{9}$ nutraceuticals ${ }^{9-11}$ and phytochemical/nutraceuticals mixtures. ${ }^{9-12}$ The majority of these studies have been conducted in in vivo models, and the overall results have demonstrated that these phytochemicals can either act alone or in combination and can modulate important regulatory pathways at the cellular and molecular levels. Structurally different and functionally unique toxicants examined in these studies have included acetaminophen, alcohols, amiodarone, cadmium chloride, dimethylnitrosamine, doxorubicin, furosemide, TCDD and thioacetamide.,8

Based on the above considerations, a unique phytochemical mixture (STG) was designed to: (1) provide nutritional support, (2) stimulate metabolism, (3) suppress appetite and (iv) provide antioxidant and anti-inflammatory support. The presence of oxidative stress in obesity is well documented. ${ }^{15}$ STG is a novel combination of three well-investigated phyto-extracts (e.g., sage, oolong tea and guarana) and two vitamins (thiamine and niacin) in a physiologically active, balanced proportion. STG is known to work optimally in conjunction with other phytochemical-nutraceutical mixtures, such as the Metabolic Nutrition Systems.

Sage (Salvia offcinalis L.) leaf extract, one of the ingredients of STG, is a widely used herb. Its extracts contain a variety of polyphenols, some of which are also found in tea. These polyphenols in combination with caffeine promote energy expenditure and fat oxidation..$^{10}$ Sage leaf constituents also possess immunomodulatory effects and its polyphenolic components exhibit antioxidant properties, including the ability to decrease reactive oxygen species, DNA fragmentation, lipid peroxidation and inflammation. ${ }^{16,17}$ Furthermore, sage extracts increase reduced glutathione (GSH) content, ${ }^{1718}$ and glutathione-S-transferase activity ${ }^{18}$ which are indicators of antioxidant and chemoprotective effects.

Another important ingredient of sage is carnosic acid, which at low doses reduces body weight gain and the accumulation of epididymal fat when rodents are kept on a high fat diet-fed. ${ }^{19}$ The components of sage extracts also have the ability to influence neuronal receptors, which has implications for modulating appetite and food intake. ${ }^{20}$ Sage extract exhibits hepatoprotective effects, stimulates the digestive tract and has cardioprotective properties. ${ }^{21}$ Sage extract has been used as a stimulant and diuretic. It suppresses pancreatic lipase activity and fat (triglyceride) accretion, which aid in body weight reduction. It can reduce $\mathrm{NF \kappa B}$, a transcription factor presumably involved in obesity. ${ }^{22}$ Sage also possesses antidiabetic and insulin-like activities. All these beneficial properties make this plant component a unique nutraceutical supplement.

For centuries, various forms of tea and tea preparations have gained appreciable popularity as a beverage worldwide. It is consumed in three basic forms; green tea, black tea and oolong tea (Camelia sinensis). Tea leaf extract contains one of the most complex mixtures of phytochemicals known to humans with over 4,000 bioactive components. Wide ranging benefits of consuming tea or tea polyphenols have been described in conjunction with various pathological conditions including, hypertension, atherosclerosis, diabeties, hypercholesterolemia, liver cancer and obesity. These effects are attributed to antioxidative, anti-thrombogenic, anti-inflammatory, hypotensive and hypocholesterolemic properties of tea polyphenols. ${ }^{23-25}$
Oolong tea has both active catechin components and the ability to support energy levels by increasing the metabolic rate and fat oxidation based on its polyphenol and caffeine contents. ${ }^{26}$ Lipolysis and antioxidant activity are additional effects due to its unusual combination of catechins and polyphenols. ${ }^{17,18}$ Oolong tea extracts increase plasma antioxidant capacity, ${ }^{27}$ and inhibit DNA damage. ${ }^{28,29}$ Some studies report its ability to suppress food intake and weight gain..$^{30-32} \mathrm{~A}$ water extract of oolong tea prevented the obesity and fatty liver induced by a high-fat diet in mice. The consumption of oolong tea over a 6-week period resulted in significant weight loss in women, thus exemplifying the clinical efficacy of oolong tea. Besides the reported thermogenic effect due to caffeine, human studies have shown that the consumption of oolong tea can accelerate energy expenditure and fat oxidation in humans. The combined effect of the polyphenolic component (EGCG) and caffeine has been theorized to be due to an inhibitory action on the enzyme catechol- $O$-methyl transferase which inactivates catecholamines. ${ }^{33,34}$ Overall, various tea components are deemed beneficial for the liver ${ }^{28,35}$ and cardiovascular health. ${ }^{36,37}$

The third phytochemical ingredient in STG is guarana (Paullinia cupana). Guarana is a rich source of caffeine, and it is a source of energy in STG. However, it also helps stimulate the metabolic rate, and can improve thermogenesis. ${ }^{38}$ The amount of caffeine present in STG is about the same as half a cup of coffee $(45 \mathrm{mg})$. Guarana containing products are popular among athletes because of their ergogenic and "fat burning" effects. ${ }^{39-41}$ The beneficial effects of guarana may also be due in part to ameliorating exercise-associated oxidative stress, ${ }^{42}$ since acute exercise is known to induce a transient increase in reactive oxygen and nitrogen species, evident by several reports of increased oxidative damage following acute bouts of aerobic and anaerobic exercise. ${ }^{42}$ Guarana seed extract exhibits powerful antioxidant activity, ${ }^{39-41}$ and in combination with vitamins/minerals improves task performance, as well as attenuates the increased mental fatigue associated with extended task performance. ${ }^{20}$ In addition, guarana extract given to mice suppressed hypoglycemia via promotion of glycogen resolution. Extracts of yerbe maté (leaves of Ilex paraguayenis) and damiana (leaves of Turnera diffusa var. aphrodisiaca) along with guarana seed extract have been shown to be useful in modulating physiological processes which influence gut motility, food intake and energy balance. Guarana extract can also prevent ventricular fibrillation. ${ }^{43}$ These studies demonstrate the multipronged role played by guarana seed extract in cell metabolism. ${ }^{38-41}$

Besides quantifiable antioxidant activity,,$^{26,41,44-48}$ the phytochemical components of STG that affect energy metabolism and fat partitioning may be helpful adjuncts in a dietary approach to wellbeing and body weight control..$^{26,46,47,50}$ Epidemiological studies have projected that global obesity and the overweight epidemic will soon outnumber several other diseases combined. Moreover, if this epidemic continues at the present rate, diabetes, hypertension and other metabolic disorders that cause morbidity and mortality will take a great toll on human health and health-care costs. Since diet management and exercise alone may not resolve an issue of this enormous magnitude, conventional 
medications and herbal supplements can be of considerable assistance. Among these two options, herbal supplements remain the top choice because of their safety. An additional testimony that most herbal supplements carry is that most of them have been tried for thousands of years in non-western cultures, and they do not pose immense health risks when consumed in balanced proportions.

The goal of this study was the assessment of the safety and efficacy of STG, a phytonutrient/vitamin combination. The specific objectives of the present investigation were to determine whether up to four month exposure of various concentrations (1X and 7X) of STG to Fisher 344 male and female rats could: (1) influence oxidative stress and genomic integrity of the liver, heart and kidneys; (2) change histopathology of multiple vital target organs (heart, kidneys, liver); (3) influence weight gain/ loss; and (iv) alter serum chemistry profiles (carbohydrate, lipid, protein, electrolyte and enzyme profiles). This study employed not only a human-equivalent dose (1X) but also a seven-fold higher dose $(7 \mathrm{X})$ to study serum chemistry and organ histopathology of seven vital target organs. Since the liver is the primary site of metabolism and detoxification of most xenobiotics, kidney is the principal site of excretion of toxic products and heart is the central organ of the cardiovascular system, oxidative stress and genomic integrity of these tissues were also analyzed.

\section{Results}

Effects of STG on food consumption and body weight. Figures 1 and 2 shows the impact of STG on these two vital parameters. Nothing was observed out of the ordinary during the entire study. Compared to females (Fig. 2), male rats on 7X diet showed a tendency to loose weight beginning at 9 weeks and the loss in body weight was maintained until the end of the study (Fig. 1). It is quite likely that animals may have shown a significant loss of weight if this study would have continued beyond 4 months.

Effects of STG on organ specific serum parameters. Table 1 shows the effects of $1 \mathrm{X}$ and $7 \mathrm{X}$ concentrations of STG on the liver, kidneys and heart specific serum parameters. Since the liver is the primary site for xenobiotic metabolism, serum alanine aminotransferase (ALT) and aspartate aminotransferase (AST) activities were determined to monitor the liver function. Likewise, creatine kinase $(\mathrm{CK})$ and lactate dehydrogenase $(\mathrm{LDH})$ enzyme activities served as markers for cardiac function, and levels of blood urea nitrogen (BUN) and creatinine reflected functioning of the kidneys. Compared to control, ALT, AST and CK activities were slightly elevated at 2 months which returned to control levels at 4 months. LDH activity remained near normal levels at both time points.

Two months of STG exposure lowered BUN levels in males, and slightly elevated levels in females. This disparity was not observed at 4 months. In contrast, both male and female rats exhibited slightly elevated levels of creatinine at 2 months and the opposite trend at 4 months. Compared to control, overall BUN levels were low in both sexes at 4 months. None of the doses of STG significantly altered these vital organ-specific serum parameters, and indirectly reflected the lack of adverse effects of STG on

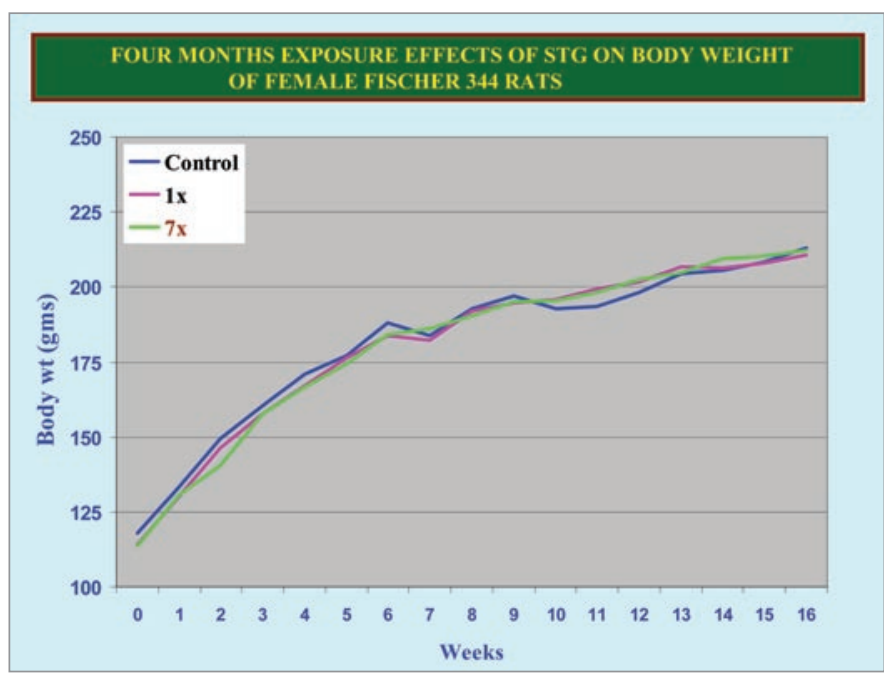

Figure 1. Continuous exposure to various doses of STG (S, sage leaf extract; T, oolong tea extract; $G$, guarana seed extract) for up to 4 months did not alter body weight of female rats. Animals in this study were divided into three groups: (1) Control; received regular rat chow (AIN-76 base diet); (2) 1X STG diet: received chow premixed with $1 \mathrm{X}$ human equivalent dose of STG based on a $70 \mathrm{~kg}$ human receiving $192 \mathrm{mg}$ of STG per kg body wt; (3) 7X STG diet: received chow premixed with 7X human equivalent of STG. Pre-formulated STG-vitamin mixture (see methods for details) in the form of a powder was used in this study.

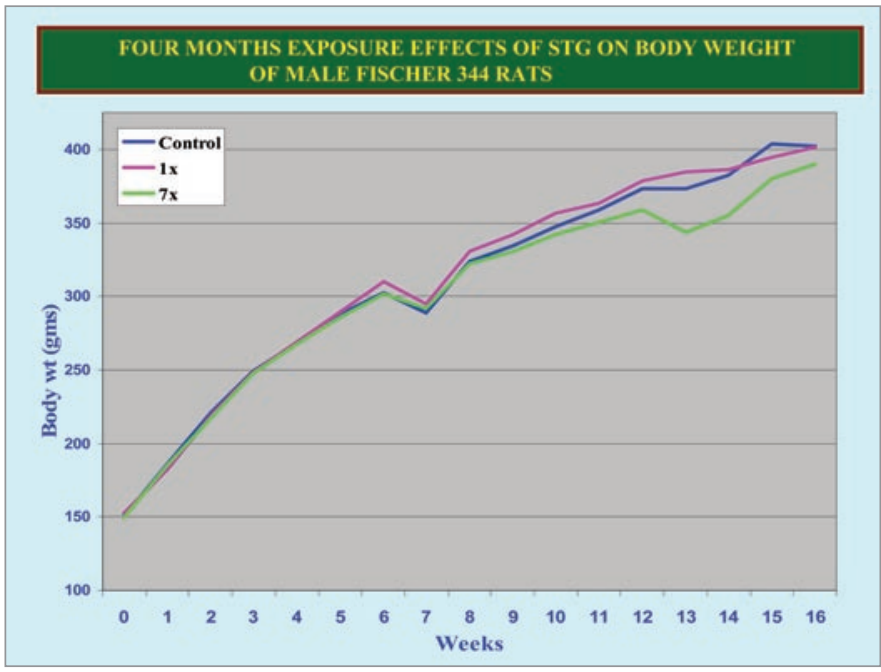

Figure 2. Continuous exposure to various doses of STG for up to 4 months slightly reduced body weight of male rats. However, weight reduction was observed only with high dose of 7X STG just prior to 4 months and the lower dose did not show any effect at all. See animal treatment details in Figure 1.

these organs up until 4 months. However, compared to 2 months, all these serum markers showed a slightly declining trend at 4 months. Except BUN and creatinine, animal gender did not play a role in influencing these parameters. Based on this scenario, it can be safely concluded that, up to 4 months of exposure, STG was safe to these three organs and it did not significantly alter 
Table 1. Effects of up to 4 months of STG exposure on liver, kidney and heart specific serum markers and lipid profiles of Fisher 344 male and female rats

\begin{tabular}{|c|c|c|c|c|c|c|c|c|c|c|c|c|}
\hline \multirow{2}{*}{$\begin{array}{c}\text { Serum } \\
\text { parameters } \\
\text { (units) }\end{array}$} & \multicolumn{3}{|c|}{ Female (2 Mo) } & \multicolumn{3}{|c|}{ Male (2 Mo) } & \multicolumn{3}{|c|}{ Female (4 Mo) } & \multicolumn{3}{|c|}{ Male (4 Mo) } \\
\hline & Con & $1 x$ & $7 x$ & Con & $1 x$ & $7 x$ & Con & $1 x$ & $7 x$ & Con & $1 x$ & $7 x$ \\
\hline ALT (IU/L) & $46 \pm 4$ & $54 \pm 5$ & $4 \pm 5$ & $\begin{array}{c}75 \pm \\
10\end{array}$ & $78 \pm 11$ & $59 \pm 8$ & $41 \pm 3$ & $46 \pm 6$ & $46 \pm 3$ & $47 \pm 5$ & $54 \pm 6$ & $57 \pm 8$ \\
\hline AST (IU/L) & $75 \pm 2$ & $96 \pm 3$ & $99 \pm 10$ & $95 \pm 2$ & $104 \pm 2$ & $89 \pm 3$ & $83 \pm 6$ & $79 \pm 5$ & $78 \pm 6$ & $57 \pm 17$ & $72 \pm 3$ & $76 \pm 4$ \\
\hline CK (IU/L) & $269 \pm 9$ & $\begin{array}{c}589 \pm \\
60\end{array}$ & $\begin{array}{c}380 \pm \\
23\end{array}$ & $\begin{array}{l}281 \\
\pm 4\end{array}$ & $256 \pm 9$ & $395 \pm 2$ & $\begin{array}{c}181 \pm \\
15\end{array}$ & $\begin{array}{c}203 \pm \\
35\end{array}$ & $\begin{array}{c}106 \pm \\
26\end{array}$ & $\begin{array}{c}172 \pm \\
31\end{array}$ & $\begin{array}{c}121 \pm \\
11\end{array}$ & $221 \pm 45$ \\
\hline LDH (IU/L) & $\begin{array}{c}300 \pm \\
11\end{array}$ & $45 \pm 11$ & $236 \pm 42$ & $\begin{array}{l}275 \\
\pm 5\end{array}$ & $\begin{array}{c}266 \pm \\
12\end{array}$ & $09 \pm 41$ & $\begin{array}{c}141 \pm \\
14\end{array}$ & $131 \pm 18$ & $98 \pm 13$ & $\begin{array}{c}128 \pm \\
27\end{array}$ & $\begin{array}{c}121 \pm \\
22\end{array}$ & $140 \pm 24$ \\
\hline $\begin{array}{l}\text { BUN (MG/ } \\
\text { DL) }\end{array}$ & $18 \pm 2$ & \pm 2 & \pm 2 & $24 \pm 2$ & $21 \pm 2$ & $6 \pm 1$ & $16 \pm 1$ & $18 \pm 1$ & $18 \pm 1$ & $18 \pm 0.3$ & $\begin{array}{c}18 \pm \\
0.9\end{array}$ & $21 \pm 0.9$ \\
\hline $\begin{array}{l}\text { Creatinine } \\
\text { (MG/DL) }\end{array}$ & $\begin{array}{c}0.47 \pm \\
0.03\end{array}$ & $\begin{array}{c}0.63 \pm \\
0.03\end{array}$ & $\begin{array}{c}0.57 \pm \\
0.03\end{array}$ & $\begin{array}{c}0.43 \pm \\
0.3\end{array}$ & $\begin{array}{c}0.50 \pm \\
0.00\end{array}$ & $\begin{array}{l}0.50 \pm \\
0.06\end{array}$ & $\begin{array}{c}0.47 \pm \\
0.09\end{array}$ & $\begin{array}{c}0.34 \pm \\
0.03\end{array}$ & $\begin{array}{c}0.34 \pm \\
0.03\end{array}$ & $\begin{array}{c}0.60 \pm \\
0.06\end{array}$ & $\begin{array}{c}0.40 \pm \\
0.05\end{array}$ & $\begin{array}{c}0.27 \pm \\
0.06\end{array}$ \\
\hline $\begin{array}{l}\text { Cholesterol } \\
(\mathrm{mg} / \mathrm{dL})\end{array}$ & $\begin{array}{c}130.7 \pm \\
0.90\end{array}$ & $\begin{array}{c}102.7 \pm \\
0.90\end{array}$ & $\begin{array}{c}112.3 \pm \\
7.53\end{array}$ & $\begin{array}{l}140.7 \\
\pm 0.33\end{array}$ & $\begin{array}{c}123.7 \pm \\
1.45\end{array}$ & $\begin{array}{c}125.3 \pm \\
2.73\end{array}$ & $\begin{array}{c}123.0 \pm \\
2.52\end{array}$ & $\begin{array}{c}134.0 \pm \\
5.77\end{array}$ & $\begin{array}{c}134.7 \pm \\
2.73\end{array}$ & $\begin{array}{c}135.0 \pm \\
10.0\end{array}$ & $\begin{array}{c}175.7 \pm \\
12.8\end{array}$ & $\begin{array}{l}163.0 \pm \\
7.02\end{array}$ \\
\hline $\begin{array}{c}\mathrm{HDL}(\mathrm{mg} / \\
\mathrm{dL})\end{array}$ & $\begin{array}{c}67.30 \pm \\
0.70\end{array}$ & $\begin{array}{c}62.80 \pm \\
2.63\end{array}$ & $\begin{array}{c}63.30 \pm \\
5.53\end{array}$ & $\begin{array}{l}62.67 \\
\pm 0.33\end{array}$ & $\begin{array}{c}68.90 \pm \\
2.60\end{array}$ & $\begin{array}{c}68.03 \pm \\
1.73\end{array}$ & $\begin{array}{c}45.00 \pm \\
0.58\end{array}$ & $\begin{array}{c}48.67 \pm \\
2.19\end{array}$ & $\begin{array}{c}50.00 \pm \\
0.58^{*}\end{array}$ & $\begin{array}{c}39.67 \pm \\
3.28\end{array}$ & $\begin{array}{l}53.67 \pm \\
0.33^{*}\end{array}$ & $\begin{array}{c}52.33 \pm \\
6.94^{*}\end{array}$ \\
\hline $\begin{array}{l}\text { Triglycerides } \\
\text { (mg/dL) }\end{array}$ & $\begin{array}{c}260.0 \pm \\
3.06\end{array}$ & $\begin{array}{c}202.3 \pm \\
5.18^{*}\end{array}$ & $\begin{array}{c}147.3 \pm \\
20.1^{*}\end{array}$ & $\begin{array}{l}360.0 \\
\pm 2.08\end{array}$ & $\begin{array}{c}475.3 \pm \\
7.69^{*}\end{array}$ & $\begin{array}{c}257.7 \pm \\
1.33^{*}\end{array}$ & $\begin{array}{c}164.7 \pm \\
26.0\end{array}$ & $\begin{array}{c}196.3 \pm \\
24.7^{*}\end{array}$ & $\begin{array}{c}200.7 \pm \\
34.8^{*}\end{array}$ & $\begin{array}{c}518.0 \pm \\
56.9\end{array}$ & $\begin{array}{c}658.0 \\
\pm 36.0^{*}\end{array}$ & $\begin{array}{c}649.0 \pm \\
15.4^{*}\end{array}$ \\
\hline $\begin{array}{l}\text { VLDL } \\
(\mathrm{mEq} / \mathrm{L})\end{array}$ & $\begin{array}{c}52.00 \pm \\
0.58\end{array}$ & $\begin{array}{c}40.67 \pm \\
1.33^{*}\end{array}$ & $\begin{array}{c}29.33 \pm \\
3.90^{*}\end{array}$ & $\begin{array}{l}72.00 \\
\pm 0.57\end{array}$ & $\begin{array}{c}95.00 \pm \\
1.53^{*}\end{array}$ & $\begin{array}{c}51.67 \pm \\
0.33^{*}\end{array}$ & $\begin{array}{c}33.00 \pm \\
5.13\end{array}$ & $\begin{array}{c}39.33 \pm \\
4.80\end{array}$ & $\begin{array}{c}40.00 \pm \\
7.00\end{array}$ & $\begin{array}{c}103.7 \pm \\
11.3\end{array}$ & $\begin{array}{l}131.7 \pm \\
7.13^{*}\end{array}$ & $\begin{array}{c}129.7 \pm \\
3.18^{*}\end{array}$ \\
\hline $\mathrm{LDL}(\mathrm{mEq} / \mathrm{L})$ & $\begin{array}{c}11.33 \pm \\
1.62\end{array}$ & $\begin{array}{c}13.87 \pm \\
1.83\end{array}$ & $\begin{array}{c}34.20 \pm \\
0.83^{*}\end{array}$ & $\begin{array}{l}06.00 \\
\pm 0.42\end{array}$ & $\begin{array}{c}00.00 \pm \\
0.00\end{array}$ & $\begin{array}{c}38.40 \pm \\
1.30\end{array}$ & $\begin{array}{c}45.00 \pm \\
7.77\end{array}$ & $\begin{array}{c}46.00 \pm \\
6.08\end{array}$ & $\begin{array}{c}44.67 \pm \\
9.90\end{array}$ & $\begin{array}{c}06.33 \pm \\
0.65\end{array}$ & $\begin{array}{c}04.00 \\
\pm 0.36^{*}\end{array}$ & $\begin{array}{c}00.00 \pm \\
0.00^{*}\end{array}$ \\
\hline $\begin{array}{l}\text { LDL/HDL } \\
\text { Ratio }\end{array}$ & $\begin{array}{c}00.17 \pm \\
0.03\end{array}$ & $\begin{array}{c}00.30 \pm \\
0.06\end{array}$ & $\begin{array}{c}00.73 \pm \\
0.07\end{array}$ & $\begin{array}{c}00.10 \\
\pm 0.00\end{array}$ & $\begin{array}{c}00.00 \pm \\
0.00\end{array}$ & $\begin{array}{c}00.73 \pm \\
0.03\end{array}$ & $\begin{array}{c}00.97 \pm \\
0.18\end{array}$ & $\begin{array}{c}00.93 \pm \\
0.13\end{array}$ & $\begin{array}{c}00.93 \pm \\
0.20\end{array}$ & $\begin{array}{c}00.13 \pm \\
0.00\end{array}$ & $\begin{array}{l}00.07 \\
\pm 0.01\end{array}$ & $\begin{array}{c}00.00 \pm \\
0.00\end{array}$ \\
\hline
\end{tabular}

Values represent Mean $\pm \mathrm{SE}, \mathrm{n}=3 ;{ }^{*} \mathrm{p} \leq 0.05$ Control vs. treated if indicated; Human reference ranges- ALT: 12-31 IU/L; AST: 0-37 IU/L; Creatine phosphokinase: 20-184 IU/L; LDH: 89-187 IU/L; BUN: 8-23 MG/DL; Creatinine: 0.5-1.2 MG/DL; Total cholesterol: 140-200; HDL: 35-60; Triglycerides: 10-190; VLDL: 5-40; LDL: 62-130; LDL-HDL Ratio: 1-3.55.

functioning of these organs. None of the animals became ill or died during this 4 month exposure to STG.

Tables $2 \mathrm{~A}$ and $\mathrm{B}$ show changes in serum protein, lipid and protein profiles, and electrolytes. Most parameters remained near control levels. Small fluctuations and variations in values occurred based on gender, dose of STG (1X vs. 7X), duration of treatment ( 2 vs. 4 months), and the fact that each value is the mean with the SE for three animals. However, no glaring changes occurred that would have been indicative of an adverse or toxicological event.

Effects of STG on organellar oxidative stress. Figures 3-5 depict levels of oxidative stress in various organs upon STG exposure. Oxidative stress was indirectly quantitated in the three organs via measuring a lipid peroxidation byproduct, malondialdehyde (MDA). The most remarkable observation was absence of an increased stress due to STG, and in contrast, liver and heart tissues showed considerably reduced accumulation of MDA (as reflected by of lipid peroxidation). However, kidneys were unresponsive to STG stimuli. This scenario was anticipated based on the effects of STG on SOD and GPx activities which serve as scavengers of free radicals in the respective tissues. Additionally, it was observed that the female livers showed a dose-response at both time points but the males did not. In the heart, gender did not play a role and both male and females showed a consistent dose response. Overall, timing of exposure did not appear to play a major role.

Effects of STG on organ specific SOD activity. Figures 6-8 present effects of STG on SOD activity in various organs. Tissue SOD activity is considered a prime component of the intracellular antioxidant team. The primary role of SOD is to neutralize the normally produced tissue burden of superoxide during cellular metabolism/catabolism ultimately forming $\mathrm{H}_{2} \mathrm{O}_{2} \cdot \mathrm{H}_{2} \mathrm{O}_{2}$ is then further degraded into water and oxygen by other enzyme systems. Although unanticipated, exposure to STG revealed considerable changes in tissue SOD activity. In general, SOD activity increased as compared to controls in both sexes at both time points. Female animals showed a slightly greater induction of SOD compared to males, and STG produced a modestly greater induction of SOD in the liver and heart compared to the kidneys. Likewise, duration of exposure exhibited a minimal effect on the overall induction of this enzyme. SOD induction by STG did show a dose-response effect. Enzyme activity was found to be $>2$-fold by $7 \mathrm{x}$ and $<2$-fold by $1 \mathrm{x}$ in the liver and heart. However, kidneys responded poorly to STG and the increase was $<1.5$-fold at both doses. Male rats showed a slightly greater response at 2 months. 
Table 2. (A) Effects of up to 4 months of STG exposure on serum glucose, bilirubin and protein profiles of Fisher 344 male and female rats

\begin{tabular}{|c|c|c|c|c|c|c|c|c|c|c|c|c|}
\hline \multirow{2}{*}{ Protein (units) } & \multicolumn{3}{|c|}{ Female ( 2 months) } & \multicolumn{3}{|c|}{ Male (2 months) } & \multicolumn{3}{|c|}{ Female (4 months) } & \multicolumn{3}{|c|}{ Male (4 months) } \\
\hline & Con & $1 x$ & $7 x$ & Con & $1 x$ & $7 x$ & Con & $1 x$ & $7 x$ & Con & $1 x$ & $7 x$ \\
\hline $\begin{array}{c}\text { Glucose (mg/ } \\
\text { dL) }\end{array}$ & $\begin{array}{c}233 \pm \\
10.0\end{array}$ & $\begin{array}{c}237 \pm \\
4.00\end{array}$ & $\begin{array}{l}282 \pm \\
33.00\end{array}$ & $\begin{array}{c}210 \pm \\
1.50\end{array}$ & $\begin{array}{c}245 \pm \\
4.00\end{array}$ & $\begin{array}{c}318 \pm \\
3.80\end{array}$ & $\begin{array}{c}166 \pm \\
4.00\end{array}$ & $\begin{array}{c}167 \pm \\
10.0\end{array}$ & $\begin{array}{c}168 \pm \\
8.00\end{array}$ & $\begin{array}{c}207 \pm \\
4.50\end{array}$ & $\begin{array}{c}203 \pm \\
9.00\end{array}$ & $\begin{array}{l}156 \pm \\
11.00\end{array}$ \\
\hline $\begin{array}{l}\text { Tot. Protein } \\
\text { (g/dL) }\end{array}$ & $\begin{array}{c}7.50 \pm \\
0.0\end{array}$ & $\begin{array}{c}7.10 \pm \\
0.10\end{array}$ & $\begin{array}{c}6.80 \pm \\
0.20\end{array}$ & $\begin{array}{c}7.70 \pm \\
1.00\end{array}$ & $\begin{array}{c}6.90 \pm \\
1.00\end{array}$ & $\begin{array}{c}6.50 \pm \\
0.06\end{array}$ & $\begin{array}{c}7.30 \pm \\
0.17\end{array}$ & $\begin{array}{c}7.60 \pm \\
0.21\end{array}$ & $\begin{array}{c}7.60 \pm \\
0.17\end{array}$ & $\begin{array}{c}8.20 \pm \\
0.06\end{array}$ & $\begin{array}{c}8.90 \pm \\
0.06\end{array}$ & $\begin{array}{c}8.70 \pm \\
0.20\end{array}$ \\
\hline $\begin{array}{l}\text { Albumin }(A) \\
\qquad(g / d L)\end{array}$ & $\begin{array}{l}3.9 \pm \\
0.03\end{array}$ & $\begin{array}{l}3.6 \pm \\
0.06\end{array}$ & $\begin{array}{c}3.50 \pm \\
0.10\end{array}$ & $\begin{array}{c}3.80 \pm \\
0.03\end{array}$ & $\begin{array}{c}3.40 \pm \\
0.03\end{array}$ & $\begin{array}{c}3.40 \pm \\
0.03\end{array}$ & $\begin{array}{c}3.80 \pm \\
0.18\end{array}$ & $\begin{array}{c}4.10 \pm \\
0.06\end{array}$ & $\begin{array}{c}4.00 \pm \\
0.14\end{array}$ & $\begin{array}{c}3.57 \pm \\
0.14\end{array}$ & $\begin{array}{c}4.00 \pm \\
0.12\end{array}$ & $\begin{array}{c}3.96 \pm \\
0.12\end{array}$ \\
\hline $\begin{array}{l}\text { Globulin (G) } \\
\text { (g/dL) }\end{array}$ & $\begin{array}{c}3.60 \pm \\
0.03\end{array}$ & $\begin{array}{c}3.40 \pm \\
0.03\end{array}$ & $\begin{array}{c}3.30 \pm \\
0.17\end{array}$ & $\begin{array}{c}3.87 \pm \\
1.3\end{array}$ & $\begin{array}{c}3.40 \pm \\
0.09\end{array}$ & $\begin{array}{c}3.06 \pm \\
0.09\end{array}$ & $\begin{array}{c}3.46 \pm \\
0.03\end{array}$ & $\begin{array}{c}3.50 \pm \\
0.20\end{array}$ & $\begin{array}{c}3.60 \pm \\
0.17\end{array}$ & $\begin{array}{c}4.63 \pm \\
0.12\end{array}$ & $\begin{array}{c}4.90 \pm \\
0.6\end{array}$ & $\begin{array}{c}4.77 \pm \\
0.09\end{array}$ \\
\hline A/G Ratio & 1.10 & 1.06 & 1.06 & 1.03 & 0.97 & 1.13 & 1.13 & 1.20 & 1.13 & 0.80 & 0.83 & 0.83 \\
\hline $\begin{array}{c}\text { Alkaline } \\
\text { Phosphatase } \\
\text { (Units/L) }\end{array}$ & $\begin{array}{c}183 \pm \\
3.48\end{array}$ & $\begin{array}{c}178 \pm \\
0.88\end{array}$ & $\begin{array}{c}157 \pm \\
9.60\end{array}$ & $\begin{array}{c}184 \pm \\
1.66\end{array}$ & $\begin{array}{c}191 \pm \\
3.40\end{array}$ & $\begin{array}{c}144 \pm \\
0.90\end{array}$ & $\begin{array}{c}140 \pm \\
10.0\end{array}$ & $\begin{array}{c}138 \pm \\
1.30\end{array}$ & $\begin{array}{c}120 \pm \\
7.50\end{array}$ & $\begin{array}{c}119 \pm \\
3.93\end{array}$ & $\begin{array}{c}121 \pm \\
2.30\end{array}$ & $\begin{array}{c}129 \pm \\
3.70\end{array}$ \\
\hline $\begin{array}{l}\text { C-Reactive } \\
\text { Protein (mg/ } \\
\text { dL) }\end{array}$ & $\begin{array}{r}0.070 \\
\pm 0.03\end{array}$ & $\begin{array}{l}0.100 \\
\pm 0.0\end{array}$ & $\begin{array}{c}0.133 \pm \\
0.03\end{array}$ & $\begin{array}{c}0.130 \pm \\
0.03\end{array}$ & $\begin{array}{c}0.670 \pm \\
0.03\end{array}$ & $\begin{array}{c}0.070 \pm \\
0.03\end{array}$ & $\begin{array}{c}0.170 \pm \\
0.06\end{array}$ & $\begin{array}{c}0.100 \pm \\
0.0\end{array}$ & $\begin{array}{c}0.100 \pm \\
0.06\end{array}$ & $\begin{array}{r}0.100 \\
\pm 0.00\end{array}$ & $\begin{array}{c}0.160 \pm \\
0.03\end{array}$ & $\begin{array}{c}0.060 \pm \\
0.03\end{array}$ \\
\hline $\begin{array}{l}\text { Homocysteine } \\
(\mu \mathrm{Mol} / \mathrm{L}\end{array}$ & $\begin{array}{c}17.2 \pm \\
1.40\end{array}$ & $\begin{array}{l}15.8 \pm \\
0.802\end{array}$ & $\begin{array}{c}15.70 \pm \\
2.02\end{array}$ & $\begin{array}{c}20.20 \pm \\
1.40\end{array}$ & $\begin{array}{c}19.10 \pm \\
3.00\end{array}$ & $\begin{array}{c}17.60 \pm \\
1.30\end{array}$ & $\begin{array}{c}15.90 \pm \\
0.50\end{array}$ & $\begin{array}{c}14.90 \pm \\
0.97\end{array}$ & $\begin{array}{c}13.60 \pm \\
1.23\end{array}$ & $\begin{array}{r}16.40 \\
\pm 1.70\end{array}$ & $\begin{array}{c}17.70 \pm \\
1.18\end{array}$ & $\begin{array}{c}15.70 \pm \\
0.48\end{array}$ \\
\hline $\begin{array}{l}\text { Bilirubin (mg/ } \\
\text { dL) }\end{array}$ & $\begin{array}{c}0.77 \pm \\
0.03\end{array}$ & $\begin{array}{c}0.57 \pm \\
0.03\end{array}$ & $\begin{array}{c}0.40 \pm \\
0.06\end{array}$ & $\begin{array}{c}0.50 \pm \\
0.00\end{array}$ & $\begin{array}{c}0.60 \pm \\
0.00\end{array}$ & $\begin{array}{c}0.33 \pm \\
0.03\end{array}$ & $\begin{array}{c}0.67 \pm \\
0.08\end{array}$ & $\begin{array}{c}0.63 \pm \\
0.06\end{array}$ & $\begin{array}{c}0.56 \pm \\
0.12\end{array}$ & $\begin{array}{c}0.76 \pm \\
0.09\end{array}$ & $\begin{array}{c}1.16 \pm \\
0.14\end{array}$ & $\begin{array}{c}0.83 \pm \\
0.09\end{array}$ \\
\hline
\end{tabular}

Values represent mean $\pm \mathrm{SE}, \mathrm{n}=3$; ${ }^{\mathrm{p}} \mathrm{p} \leq 0.05$ Control vs. treated if indicated; Human reference range: Glucose: 70-105; Tot. protein: 6.0-8.0; Albumin: 3.5-5.2; Globulin: 1.5-3.0; A/G ratio: 1.5-2.5; Alk. Phos.: 0-138; C-Reactive protein: 0-3; Homocysteine: 0-12; Bilirubin: 0.2-1.0.

Table 2. (B) Effects of up to 4 months of STG exposure on serum electrolyte profiles of Fisher 344 male and female rats

\begin{tabular}{|c|c|c|c|c|c|c|c|c|c|c|c|c|}
\hline \multirow{2}{*}{$\begin{array}{l}\text { Electrolyte } \\
\text { (units) }\end{array}$} & \multicolumn{3}{|c|}{ Female (2 Mo) } & \multicolumn{3}{|c|}{ Male (2 Mo) } & \multicolumn{3}{|c|}{ Female (4 Mo) } & \multicolumn{3}{|c|}{ Male (4 Mo) } \\
\hline & Con & $1 x$ & $7 x$ & Con & $1 x$ & $7 x$ & Con & $1 x$ & $7 x$ & Con & $1 x$ & $7 x$ \\
\hline $\begin{array}{l}\text { Calcium } \\
\text { (mg/dL) }\end{array}$ & $\begin{array}{c}10.87 \pm \\
0.03\end{array}$ & $\begin{array}{c}10.24 \pm \\
0.20\end{array}$ & $\begin{array}{c}10.57 \pm \\
0.19\end{array}$ & $\begin{array}{c}11.37 \pm \\
0.18\end{array}$ & $\begin{array}{c}10.53 \pm \\
0.12\end{array}$ & $\begin{array}{c}10.37 \pm \\
0.03\end{array}$ & $\begin{array}{c}10.03 \pm \\
0.17\end{array}$ & $\begin{array}{c}10.27 \pm \\
0.29\end{array}$ & $\begin{array}{c}10.33 \pm \\
0.09\end{array}$ & $\begin{array}{c}10.30 \pm \\
0.20\end{array}$ & $\begin{array}{c}11.07 \pm \\
0.07\end{array}$ & $\begin{array}{c}11.23 \pm \\
0.03\end{array}$ \\
\hline $\begin{array}{l}\text { Magnesium } \\
(\mathrm{mg} / \mathrm{dL})\end{array}$ & $\begin{array}{c}02.03 \pm \\
0.07\end{array}$ & $\begin{array}{c}02.63 \pm \\
0.03\end{array}$ & $\begin{array}{c}02.50 \pm \\
0.25\end{array}$ & $\begin{array}{c}03.07 \pm \\
0.03\end{array}$ & $\begin{array}{c}03.10 \pm \\
0.10\end{array}$ & $\begin{array}{c}03.00 \pm \\
0.06\end{array}$ & $\begin{array}{c}02.47 \pm \\
0.17\end{array}$ & $\begin{array}{c}02.40 \pm \\
0.29\end{array}$ & $\begin{array}{c}02.13 \pm \\
0.12\end{array}$ & $\begin{array}{c}02.47 \pm \\
0.40\end{array}$ & $\begin{array}{c}02.13 \pm \\
0.21\end{array}$ & $\begin{array}{c}02.13 \pm \\
0.07\end{array}$ \\
\hline $\begin{array}{l}\text { Potassium } \\
\text { (mEq/L) }\end{array}$ & $\begin{array}{c}04.13 \pm \\
0.15\end{array}$ & $\begin{array}{c}03.87 \pm \\
0.07\end{array}$ & $\begin{array}{c}03.94 \pm \\
0.09\end{array}$ & $\begin{array}{c}05.07 \pm \\
0.03\end{array}$ & $\begin{array}{c}04.30 \pm \\
0.06\end{array}$ & $\begin{array}{c}04.97 \pm \\
0.07\end{array}$ & $\begin{array}{c}03.97 \pm \\
0.20\end{array}$ & $\begin{array}{c}03.60 \pm \\
0.25\end{array}$ & $\begin{array}{c}03.63 \pm \\
0.15\end{array}$ & $\begin{array}{c}04.13 \pm \\
0.13\end{array}$ & $\begin{array}{c}04.56 \pm \\
0.03\end{array}$ & $\begin{array}{c}04.63 \pm \\
0.58\end{array}$ \\
\hline $\begin{array}{l}\text { Sodium } \\
\text { (mEq/L) }\end{array}$ & $\begin{array}{c}141.7 \pm \\
0.90\end{array}$ & $\begin{array}{c}144.0 \pm \\
0.57\end{array}$ & $\begin{array}{c}144.3 \pm \\
0.89\end{array}$ & $\begin{array}{c}137.0 \pm \\
0.58\end{array}$ & $\begin{array}{c}144.0 \pm \\
0.58\end{array}$ & $\begin{array}{c}142.0 \pm \\
0.58\end{array}$ & $\begin{array}{c}139.7 \pm \\
0.89\end{array}$ & $\begin{array}{c}139.3 \pm \\
0.67\end{array}$ & $\begin{array}{c}139.7 \pm \\
0.89\end{array}$ & $\begin{array}{c}140.3 \pm \\
0.34\end{array}$ & $\begin{array}{c}140.7 \pm \\
0.67\end{array}$ & $\begin{array}{c}141.3 \pm \\
0.88\end{array}$ \\
\hline $\begin{array}{l}\text { Chloride } \\
\text { (mEq/L) }\end{array}$ & $\begin{array}{c}106.0 \pm \\
1.53\end{array}$ & $\begin{array}{c}103.3 \pm \\
2.19\end{array}$ & $\begin{array}{c}101.7 \pm \\
1.20\end{array}$ & $\begin{array}{c}102.3 \pm \\
0.67\end{array}$ & $\begin{array}{c}103.3 \pm \\
1.20\end{array}$ & $\begin{array}{c}102.3 \pm \\
0.67\end{array}$ & $\begin{array}{c}101.7 \pm \\
1.33\end{array}$ & $\begin{array}{c}102.3 \pm \\
1.20\end{array}$ & $\begin{array}{c}103.7 \pm \\
0.33\end{array}$ & $\begin{array}{c}96.00 \pm \\
1.15\end{array}$ & $\begin{array}{c}103.7 \pm \\
1.33\end{array}$ & $\begin{array}{c}102.3 \pm \\
1.20\end{array}$ \\
\hline $\begin{array}{l}\text { Phosphorus } \\
\text { (mg/dL) }\end{array}$ & $\begin{array}{c}05.53 \pm \\
0.12\end{array}$ & $\begin{array}{c}05.60 \pm \\
0.77\end{array}$ & $\begin{array}{c}06.23 \pm \\
0.12\end{array}$ & $\begin{array}{c}06.73 \pm \\
0.08\end{array}$ & $\begin{array}{c}06.04 \pm \\
0.22\end{array}$ & $\begin{array}{c}07.67 \pm \\
0.07\end{array}$ & $\begin{array}{c}06.10 \pm \\
0.46\end{array}$ & $\begin{array}{c}06.13 \pm \\
0.52\end{array}$ & $\begin{array}{c}06.03 \pm \\
0.40\end{array}$ & $\begin{array}{c}07.80 \pm \\
0.91\end{array}$ & $\begin{array}{c}06.97 \pm \\
0.15\end{array}$ & $\begin{array}{c}08.40 \pm \\
0.61\end{array}$ \\
\hline $\begin{array}{l}\text { Uric acid } \\
\text { (mg/dL) }\end{array}$ & $\begin{array}{c}01.13 \pm \\
0.12\end{array}$ & $\begin{array}{c}02.37 \pm \\
0.29^{*}\end{array}$ & $\begin{array}{c}03.63 \pm \\
0.58^{*}\end{array}$ & $\begin{array}{c}02.83 \pm \\
0.17\end{array}$ & $\begin{array}{c}02.83 \pm \\
0.03\end{array}$ & $\begin{array}{c}03.80 \pm \\
0.06^{*}\end{array}$ & $\begin{array}{c}01.00 \pm \\
0.11\end{array}$ & $\begin{array}{c}01.63 \pm \\
0.30\end{array}$ & $\begin{array}{c}01.10 \pm \\
0.20\end{array}$ & $\begin{array}{c}01.26 \pm \\
0.20\end{array}$ & $\begin{array}{c}01.20 \pm \\
0.05\end{array}$ & $\begin{array}{c}01.40 \pm \\
0.23\end{array}$ \\
\hline
\end{tabular}

Values represent mean $\pm \mathrm{SE}, \mathrm{n}=3 ;{ }^{*} \mathrm{p} \leq 0.05$ Control vs. treated if indicated; Human reference ranges- Calcium: 8.5-10.5; Magnesium: 1.6-2.6; 3.2-5.4; Sodium: 133-146; Chloride: 95-106; Uric acid: 2.6-7.2.

Effects of STG on organ specific GPx activity. Figures 9-11 depict the effects of STG on GPx activity. Ongoing action of SOD usually produces $\mathrm{H}_{2} \mathrm{O}_{2}$, and this data is consistent with the foregoing results on SOD activity (Figs. 6-8). The enzyme GPx primarily acts on $\mathrm{H}_{2} \mathrm{O}_{2}$ and breaks it down to water and oxygen. Interestingly, STG-exposure showed a differential effect on this enzyme activity in different target organs. Liver exhibited the maximum induction and the kidneys the least. In the liver, induction level was higher ( $>2$-fold) at 4 months compared to 2 months, the $7 \mathrm{X}$ dose showed a greater response compared to $1 \mathrm{X}$, and dose-response effect was similar in both genders. In contrast, heart showed a reduced response overall. In the heart, GPX activity was slightly higher in males compared to females at 2 months, whereas both genders exhibited a two-fold increase at 4 months. With respect to the kidney GPx response, both doses and both genders showed a very modest increase $(<1.5$-fold) except in 


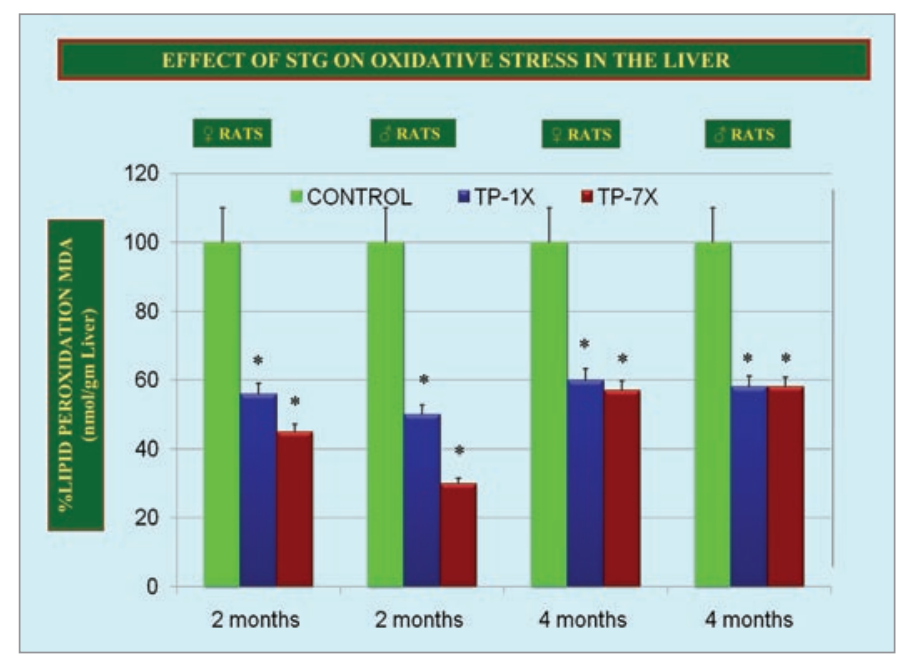

Figure 3. Four months exposure of various doses of STG (S, sage leaf extract; $T$, oolong tea extract; $G$, guarana seed extract) reduced hepatic oxidative stress (interpreted as \% malondialdehyde accumulation resulting from lipid peroxidation). STG profoundly decreased the oxidative stress level in this organ reflecting a combined antioxidative action of the components of STG. A portion of the liver tissue was homogenized, centrifuged and an aliquot of supernatant was reacted with TBA to determine TBARS. The absorbance of the resulting pink colored solution was used to determine MDA concentrations derived from a standard curve (prepared using pure MDA; see methods for details). Data are expressed as mean $\pm S E M ; n=3$ rats per group. The value is significantly different from vehicle treated control if indicated $\left({ }^{*} p \leq 0.05\right)$.

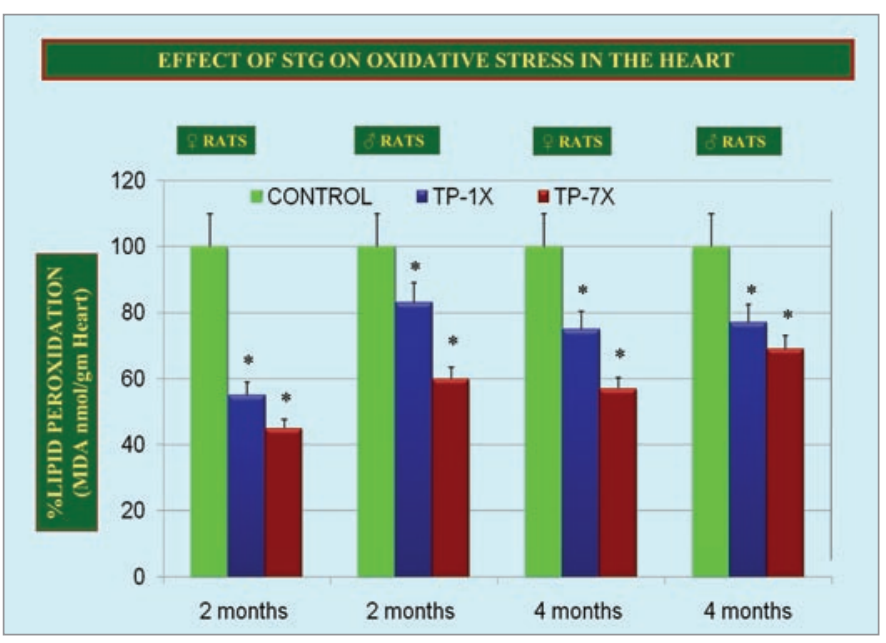

Figure 4. Four months exposure of various doses of STG reduced cardiac oxidative stress (interpreted as \% malondialdehyde accumulation resulting from lipid peroxidation). Oxidative stress in the heart indirectly reflects free radical production and its consequence, lipid peroxidation resulting in malondialdehyde accumulation. STG significantly decreased MDA accumulation in this tissue reflecting reduced level of oxidative stress. Cardiac tissue processing was identical to as described in Figure 3. Data are expressed as mean $\pm S E M . n=3$ rats per group. The value is significantly different from vehicle treated control if indicated $\left({ }^{*} p \leq 0.05\right)$. the male rats at 4 months which exhibited a slightly greater than 1.5 -fold increase in activity.

Effects of STG on total glutathione levels in various organs. Figures 12-14 show the influence of STG on total tissue glutathione levels. Although STG was able to enhance the level of this antioxidant in all the three organs, the greatest increase was observed in the liver ( $>1.5$ fold). Heart and kidney showed minimal and nearly identical responses $(<1.25$ fold). Liver also showed a time dependent increase in GSH in response to STG while the other two organs did not. In general, gender of the animals did not play a role in modulating the effect of STG, and no adverse effect on this vital antioxidant was observed. STG exhibited a dose-response effect, and overall, glutathione fluctuations strongly correlated with changes in antioxidant enzyme activities (Figs. 3-11).

Effects of STG on integrity of the total cellular DNA (genomic + mitochondrial). The impact of STG on the integrity of the total cellular DNA in the three tissues is presented in Figures 15-17. This assay is well known for its ability to reliably predict the percentage of apoptotic cell death from other forms of cell deaths. Since genomic stability is dependent upon several factors, it was important to verify the effect of STG in these three vital organs. STG did not alter the DNA integrity to any extent in the three tissues. Quantitative analysis of percent fragmented and percent intact DNA based on a sedimentation-dependent centrifugation assay revealed the intactness of the DNA in all the three organs. The percent fragmentation was insignificant. In liver and kidneys, baseline genomic injury was found to be less than control. Heart tissues were found to be neutral to STG exposure. Additionally, dose of STG, duration of exposure and animal gender did not influence the integrity of cellular DNA in the tissues.

Effects of STG on tissue histopathology. Histopathological changes in the liver, heart and kidney in response to STG ingestion are presented in Figures 18-20. Specific serum chemistry markers indirectly reflect tissue health. Tissue biochemistry in contrast, mirrors a combination of reversible and irreversible biochemical changes and histopathology exhibits actual changes at the cellular and organ level. Three representative sections from each organ from three animals were evaluated. Due to the lack of effects of 1X STG, only the pathology from the high-dose (7X) exposure is presented in this manuscript. Each figure shows one control and one 7X STG-exposed section from each organ at both time points. Both H\&E and PAS stained sections were examined, and virtually no differences were observed in the overall tissue organization and architecture. STG-exposed sections appeared practically identical to controls. Although this scenario was anticipated based on the serum chemistry and tissue biochemistry data, histopathology showed no adverse influence of STG. Examination of 1X STG exposed tissues disclosed pathological architecture identical to control sections. Overall, tissue morphology from both genders and both time points were identical following exposure to STG.

\section{Discussion}

Over the past two decades the use of phytochemicals, nutraceuticals and other herbal products have increased damatically in part due to their low level of side effects while providing health 
benefits. Expanding research and anecdotal reports of their benefits have convinced the healthcare community and the general population that naturally-derived phytochemicals have the ability to combat diseases including diabetes, HIV, inflammation, cancer, obesity and toxicant-induced organ injuries. ${ }^{1-6,19,25,42,50-53}$ Among all diseases, the obesity epidemic may be the most serious, and has attracted much attention because it has been convincingly characterized as one of the root causes of other secondary diseases such as diabetes, hypertension and cardiovascular diseases. To remedy obesity alone, the healthcare field has spent an incredible amount of resources to look for novel conventional medications and surgical procedures although overall success has been very disappointing. An alternative approach has been to use phytochemicals or dietary supplements with anti-obese properties. This approach has shown great promise and is widely applied by the general public including healthcare professionals.

STG was used in this study keeping in focus its ability to promote body's energy expenditure. Of the two doses used, $1 \mathrm{X}$ and $7 \mathrm{X}$, the higher dose showed a modest but significant weight loss in male rats at the end of 4 months (Figs. 1 and 2), whereas female rats showed no response. Several possible explanations may exist for this observation. The differences in metabolism due to gender-specific hormone profiles, very short estrus cycle of rats (every 4 days), and length of dose exposure of STG which may not have been adequate for this species to show a desired effect at the human equivalent dose may have played a role. Although it is difficult to pin point a single reason for the differences in an in vivo model, the phytochemicals in STG are now commonly used by reputable laboratories to understand cellular energy-linked mechanisms and in clinical settings to translate experimental observations to weight loss protocols.

Investigators have shown that consumption of oolong tea in combination with EGCG containing guarana caused greater energy expenditure and fat oxidation in men. ${ }^{54}$ Komatsu et al. ${ }^{46}$ reported that women who consumed oolong tea after meal increased energy expenditure by $10 \%$ compared to an energy expenditure of $4 \%$ for green tea drinkers and $0 \%$ for water drinkers. Oolong tea consumption prior to eating carbohydrate-rich foods curb increases in insulin, ${ }^{31}$ thus reducing some of the fatenhancing tendencies of carbohydrate intake, and consumption of the same product for weeks opposes obesity. ${ }^{31,52}$

It has also been suggested that tea and its components may influence glucose metabolism and diabetic hyperglycemia through several mechanisms, such as enhancing insulin sensitivity, and some human clinical studies have shown improvement in glucoregulatory control and endothelial function. ${ }^{55}$ Oolong tea leaf extracts also contain essential vitamins including $\mathrm{A}, \mathrm{B}$ complex and C, and several minerals. STG's ingredients in the presence of vitamins and minerals may have additional boosting effects on the energy expenditure or the antioxidant system. Cumulatively, all these effects suggest that oolong tea components exert control over select metabolic pathways. ${ }^{55,56}$

Pin-pointing mechanisms of actions of these naturally occurring agents remains a major challenge because of one or more of the following reasons: (1) in vitro results often do not reproduce

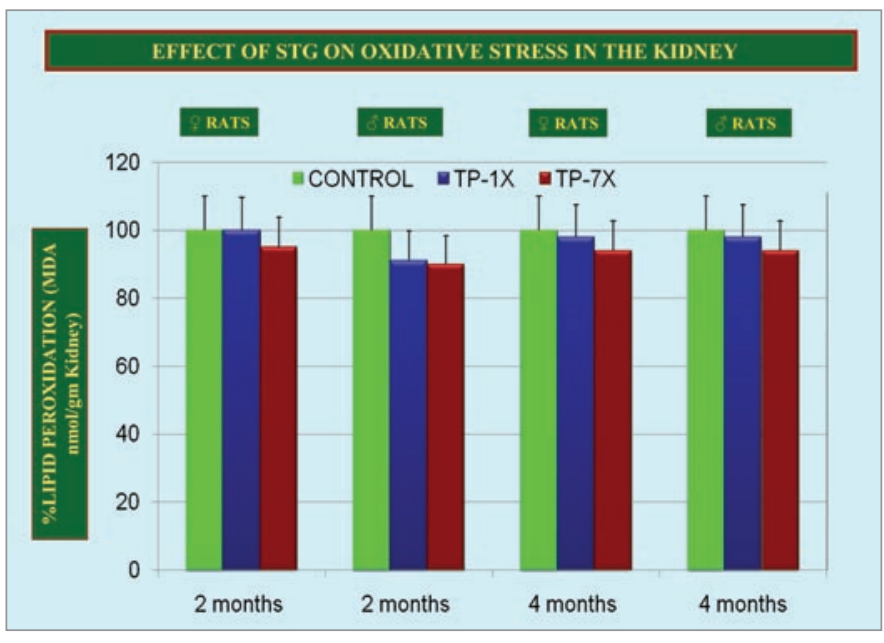

Figure 5. Four months exposure of various doses of STG did not alter kidney oxidative stress (interpreted as \% malondialdehyde accumulation resulting from lipid peroxidation). STG failed to affect this organ, indirectly reflecting no alteration in oxidative stress and a relative lack of response. Kidney tissue processing was identical to as described in Figure 3. Data are expressed as mean $\pm S E M ; n=3$ rats per group. The value is significantly different from vehicle treated control if indicated $\left({ }^{*} p \leq 0.05\right)$.

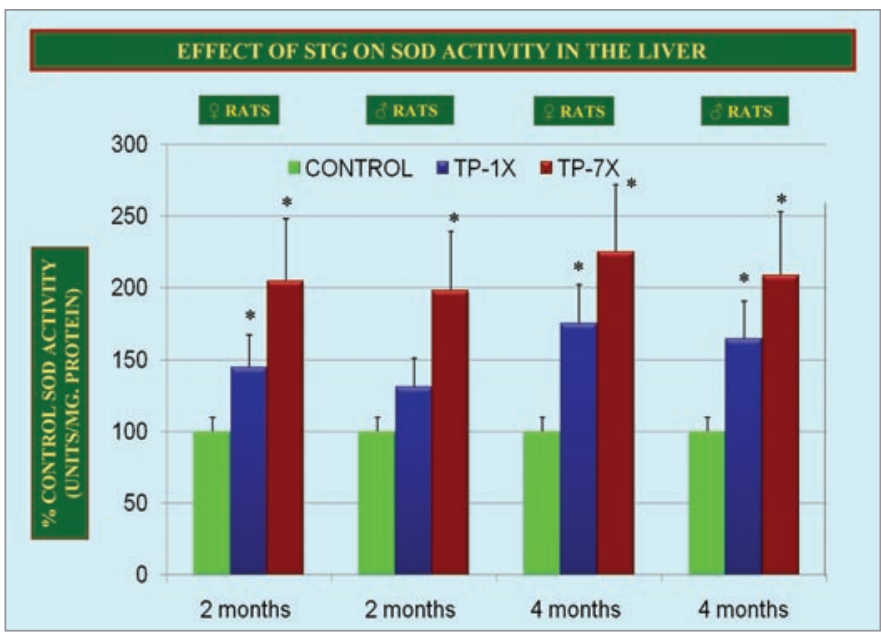

Figure 6. Four months continuous exposure of various doses of STG ( $S$, sage leaf extract; $T$, oolong tea extract; $G$, guarana seed extract) dramatically increased SOD activity in the liver. Low level of oxidative stress clearly indicated the potential of STG to induce this enzyme activity. A portion of the liver tissue was homogenized, centrifuged and the supernatant used for this assay (see methods for details). SOD activity is based on a xanthin oxidase-hypoxanthin system and absorbance is monitored at $450 \mathrm{~nm}$. Purified SOD enzyme was used to plot a standard curve. Data are expressed as mean $\pm S E M ; n=3$ rats per group. The value is significantly different from vehicle treated control if indicated $\left({ }^{*} \mathrm{p} \leq 0.05\right)$.

in vivo; (2) results derived from experimental animals may not accurately reproduce in humans; (3) a wide range of variations in human and experimental settings are often inconclusive; (iv) extrapolation of animal exposure data does not accurately suggest 


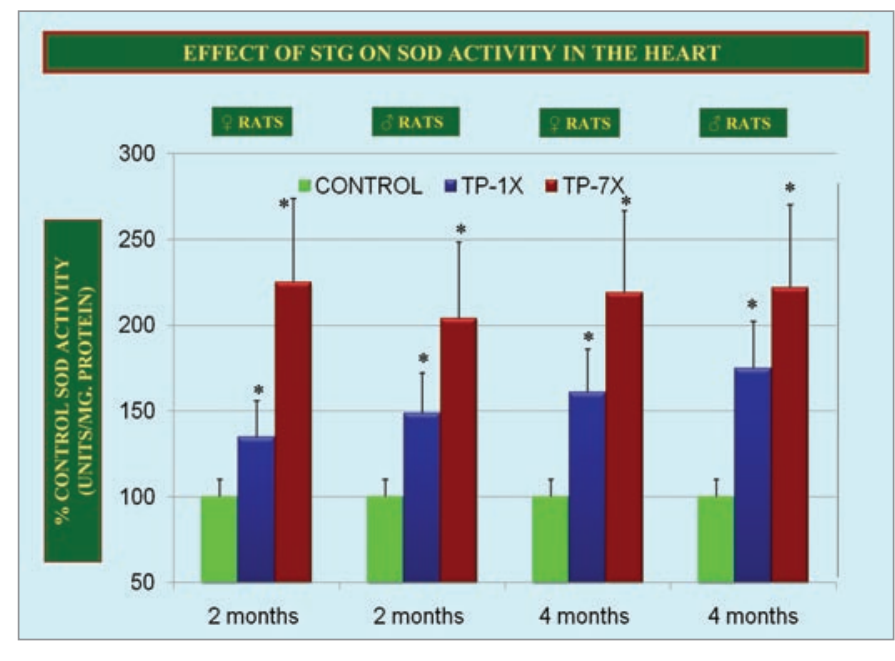

Figure 7. Four months of continuous exposure of various doses of STG dramatically increased SOD activity under low level of oxidative stress clearly indicating the potential of STG to induce the activity of this enzyme in the heart. Tissue showed a significant response to STG exposure. Data are expressed as mean $\pm \mathrm{SEM} ; \mathrm{n}=3$ rats per group. The value is significantly different from vehicle treated control if indicated $\left({ }^{*} p \leq 0.05\right)$.

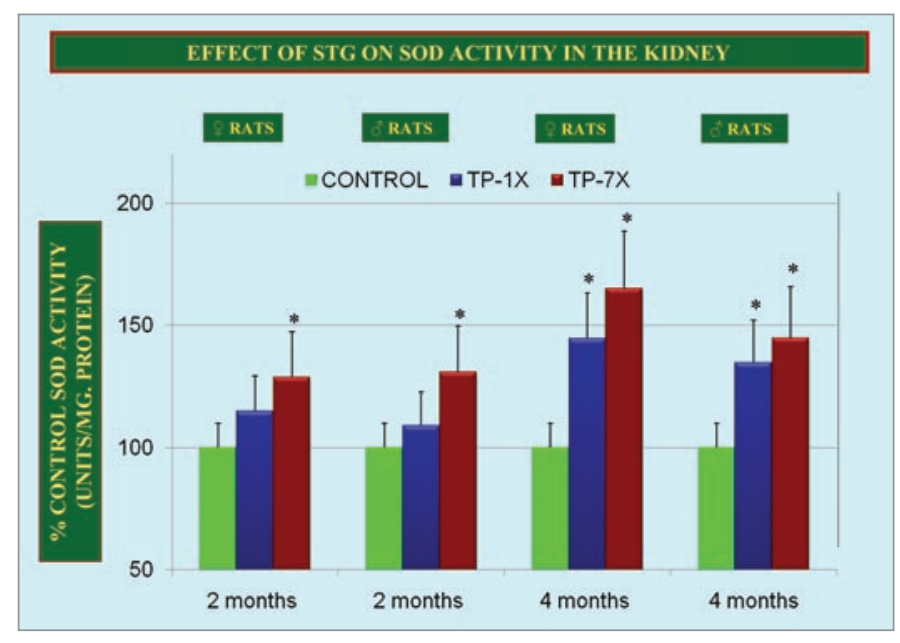

Figure 8. Four months of continuous exposure of various doses of STG showed modest increases in SOD activity under low level of oxidative stress in kidneys. Longer exposure showed a greater response compared to two months exposure. Data are expressed as mean $\pm \mathrm{SEM}$; $\mathrm{n}=3$ rats per group. The value is significantly different from vehicle treated control if indicated $\left({ }^{*} p \leq 0.05\right)$.

adequate daily intake levels in humans; and (v) bioavailability issues are additional confounding factors. The bioavailability of active components is beginning to be understood, but further research is required to determine whether the results from animal studies can be extrapolated to human setting. Nevertheless, a number of phytochemicals have progressed into clinical trials although major knowledge gaps remain to be filled. Transgenics and humanized experimental models are additional instruments that are now frequently used to understand intricacies that often do not surface and remain unnoticed during experimentation.

The second series of experiments examined specific serum markers to ascertain the safety of STG relative to vital target organs in the body (Tables 1 and 2). ALT and AST were used for the liver, BUN and creatinine were used for the kidneys and $\mathrm{CK} / \mathrm{LDH}$ were used as biomarkers for the heart to determine any adverse influence of STG. The results indicated that STG produced slightly but not significantly elevated ALT, AST and CK activities over control values in female rats and similar increases only for CK in male rats, at 2 months of treatment.

Other biochemical markers including serum glucose, bilirubin, serum lipids and electrolytes as well as $\mathrm{C}$-reactive protein and homocysteine (Tables 1 and 2) were found to be near control or below control values indicating no injury to the liver, kidneys and the heart or other tissues. Previous studies have demonstrated the absence of organ toxicity by extracts of guarana ${ }^{41}$ and sage. ${ }^{18}$ Sage has also been shown to have no effect on ALT and AST, indicators of hepatotoxicity, in humans. ${ }^{57}$ These effects of STG clearly establish safety and possibly bioavailability to three major organs and other tissues in the body.

Another series of experiments determined the influence of STG on tissue oxidative stress (Figs. 3-5) and how it modulated antioxidant pathways to minimize stress (Figs. 6-17) in all the organs. STG did not exacerbate the stress levels in any of these tissues, but rather quantifiably reduced oxidative stress in the liver and heart (Figs. 3-4) while kidneys were unaffected (Fig. 5). These results agree with previous studies demonstrating that sage extracts suppressed lipid peroxidation. ${ }^{16}$

Radical-mediated lipid peroxidation is the key to membrane injury and subsequent MDA release. MDA concentrations determined in various tissues indirectly reflect the degree of free radical mediated lipid peroxidation which is a classic indicator for cytotoxic pathways. Minimization of this event is conducive to cellular survival and normal growth. Furthermore, the fact that organ specific serum chemistry markers (Table 1 ) did not increase after STG exposure indirectly reflected either minimal or below normal production of free radicals in these tissues. Whether the observed effect was a direct interaction of ingredients of STG with the free radicals was not investigated. Besides lipid peroxidation, oxidative stress is considered the root cause of most macromolecular injury and minimization of such stress is beneficial to vital organs. Since most xenobiotics are naturally routed through the liver for biotransformation, occasionally it becomes an accidental victim. Overall, serum chemistry profiles corroborated the oxidative stress data, demonstrating little change in serum lipid and protein profiles in response to STG. Sage extract has been shown to decrease plasma LDL cholesterol and total cholesterol while increasing HDL in humans ${ }^{57}$ and rats..$^{58}$

The next series of experiments assessed the effect of STG on various antioxidant elements that play a key role in the cellular defense (Figs. 6-14). The results indicated a differential effect in the various organs. STG enhanced SOD activity in all the three organs (Figs. 6-8), although liver showed the greatest increase in a dose response manner and kidneys exhibited the lowest response. Similarly, all the three organs showed an increase 
in glutathione peroxidase activity in response to STG (Figs. 9-11), with liver producing the highest and the kidneys the lowest increase. As far as the total glutathione is concerned, again liver was the best responder to STG and kidney was the least (Figs. 15-17). Male rats responded to STG better than the female rats. These parameters mirrored unanticipated but beneficial effects of STG on these prime components of the tissue defense. These results clearly mirrored the serum chemistry profiles and patterns of oxidative stress, and agree with previous reports where sage extracts increased glutathione levels. ${ }^{17,18}$

Numerous studies have shown that the consequences of uncontrolled production of free radicals due to malnutrition, stress, depletion of cellular antioxidants due to deregulated metabolism, and free radical mediated global oxidation of vital macromolecules are prime contributors to diseases. To circumvent these issues, investigators have devised ways to artificially maneuver cellular or organ-level regulation of glutathione, vitamin C, vitamin $\mathrm{E}$, micronutrient selenium and some of the antioxidant enzymes, such as catalase, peroxidase and glutathione peroxidase. These efforts have resulted in a number of successful oxidativestress related disease fighting strategies coupled with many failures. Moreover, a universal strategy has not been found.

Over the last two decades, nutrition experts in the field have begun to recognize that naturally-derived antioxidants are significantly healthier and the myriad of phytochemicals commonly found in fruits, vegetables and edible plants are naturally designed with inherent antioxidant and chemoprotective properties. Furthermore, they rarely exhibit serious side effects and are excellent candidates for maintaining the intracellular and extracellular redox environment. This concept has impacted the basic approach to healthcare which is reflected in the continued growth in the worldwide sales of natural products in recent years.

Phytochemicals often alter cellular functions in a specialized manner without jeopardizing macromolecular conformations. Occasionally, the observed effect of a phytochemical may not be its direct effect but rather an indirect action of its metabolite(s), and many phytochemicals including those in STG have the ability to modulate biochemical events at the organ, cellular, subcellular and molecular levels.

STG was formulated such that all of its components work together and take advantage of some of these biochemical events related to free radicals and oxidative stress in various intracellular compartments. For example, polyphenols found in green tea enhance antioxidant (glutathione peroxidase, catalase and quinone reductase) and phase II (glutathione- $S$-transferase) enzyme activities, inhibit chemically induced lipid peroxidation, inhibit irradiation-and TPA-induced epidermal ornithine decarboxylase (ODC) and cyclooxygenase activities. ${ }^{56}$ Similar effects have also been reported for sage and guarana extracts. ${ }^{24,59,60}$ Consistent with the above reports, in this study, STG was found to be an excellent inducer of all the key players of the antioxidant team.

Overall length of STG exposure or gender did not significantly influence the normal functioning of the target organs but did show major differences among some of the antioxidant components. While serum chemistry parameters and the oxidative

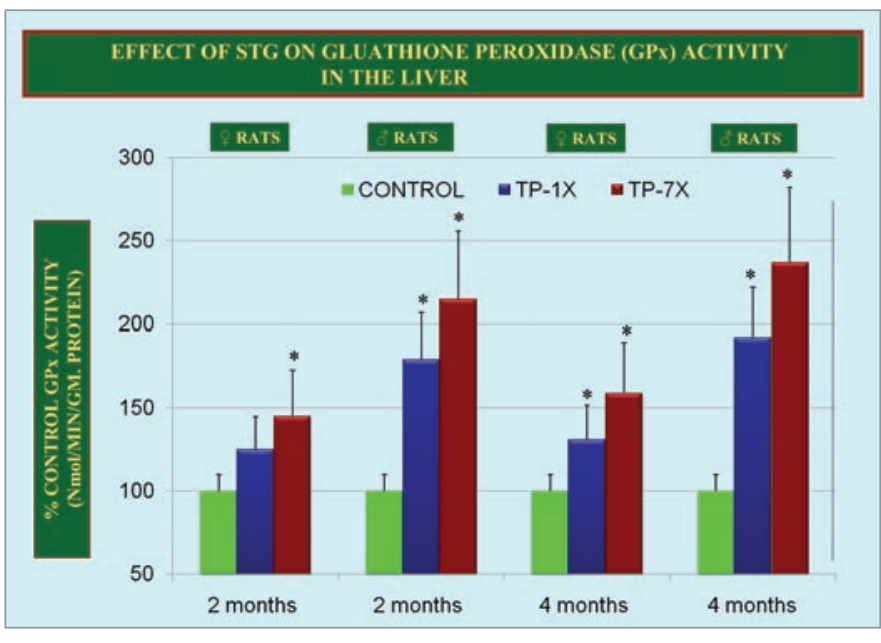

Figure 9. Four months continuous exposure of various doses of STG ( $\mathrm{S}$, sage leaf extract; $\mathrm{T}$, oolong tea extract; $\mathrm{G}$, guarana seed extract) dramatically increased GPx activity in the liver. GPx primarily neutralizes intracellular $\mathrm{H}_{2} \mathrm{O}_{2}$ and protects cells from oxidative injury. Male rats showed a greater response compared females. Enzyme activity exceeded over two fold at 2 and 4 months in male liver. Data are expressed as mean $\pm S E M ; n=3$ rats per group. The value is significantly different from vehicle treated control if indicated $\left({ }^{*} p \leq 0.05\right)$.

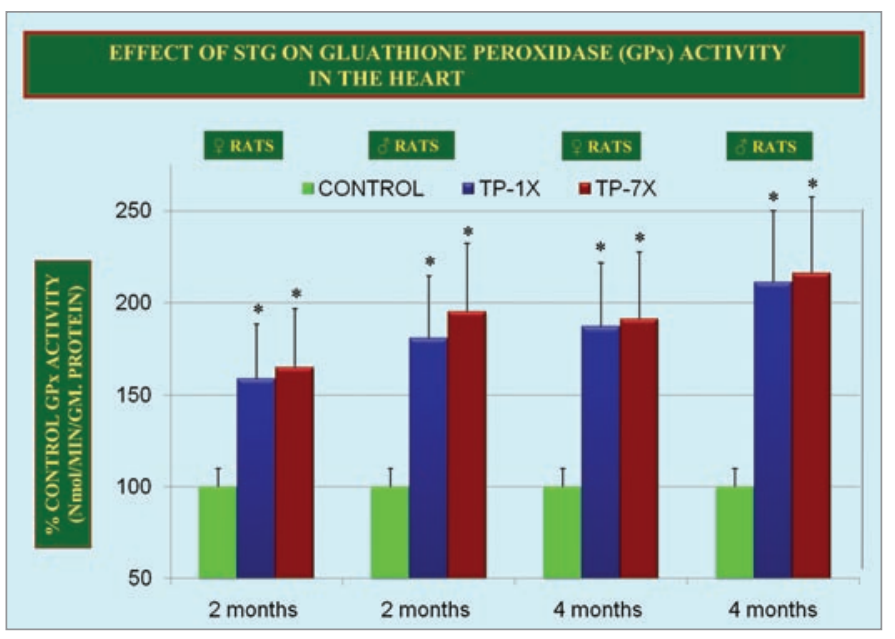

Figure 10. Four months continuous exposure of various doses of STG dramatically increased GPx activity in the heart. Female rat heart showed a slightly lesser response compared male heart. Data are expressed as mean $\pm S E M ; n=3$ rats per group. The value is significantly different from vehicle treated control if indicated $\left({ }^{*} p \leq 0.05\right)$.

stress are under the influence of free radicals, induction or inhibition of antioxidant elements are under strict genetic control. The fact that SOD, GPx and glutathione showed dramatic changes under the influence of STG suggests that the components of STG were bioavailable and accessible to intracellular compartments. However, it can not be speculated whether the components of STG acted singly or synergistically to exhibit these profound biochemical changes but experiments are in progress in our laboratories to determine such responses. The ability of the various 


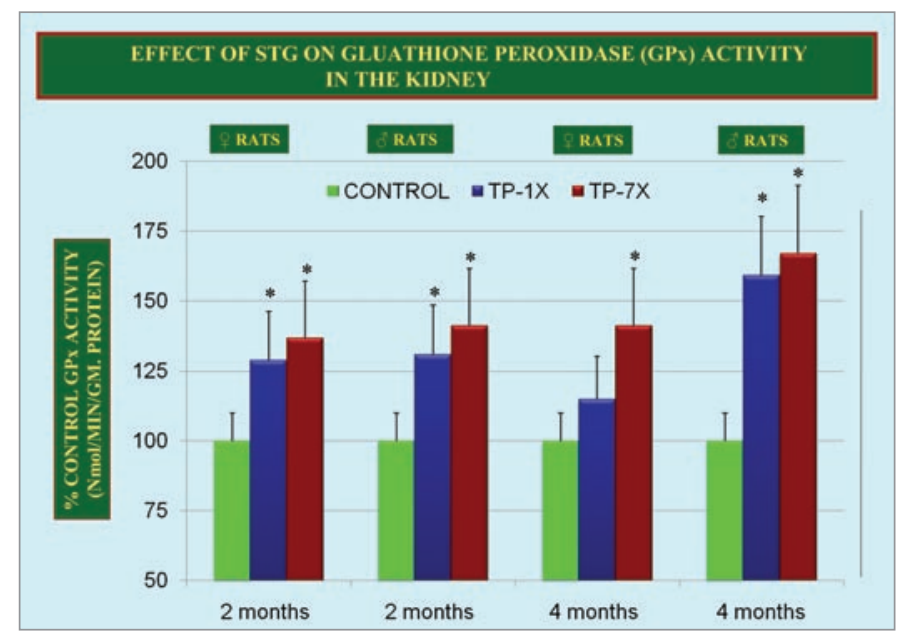

Figure 11. Four months continuous exposure of various doses of STG caused modest increases in GPx activity in kidneys. Kidney tissues were slightly less responsive compared to the liver and heart. Data are expressed as mean $\pm S E M ; n=3$ rats per group. The value is significantly different from vehicle treated control if indicated $\left({ }^{*} p \leq 0.05\right)$.

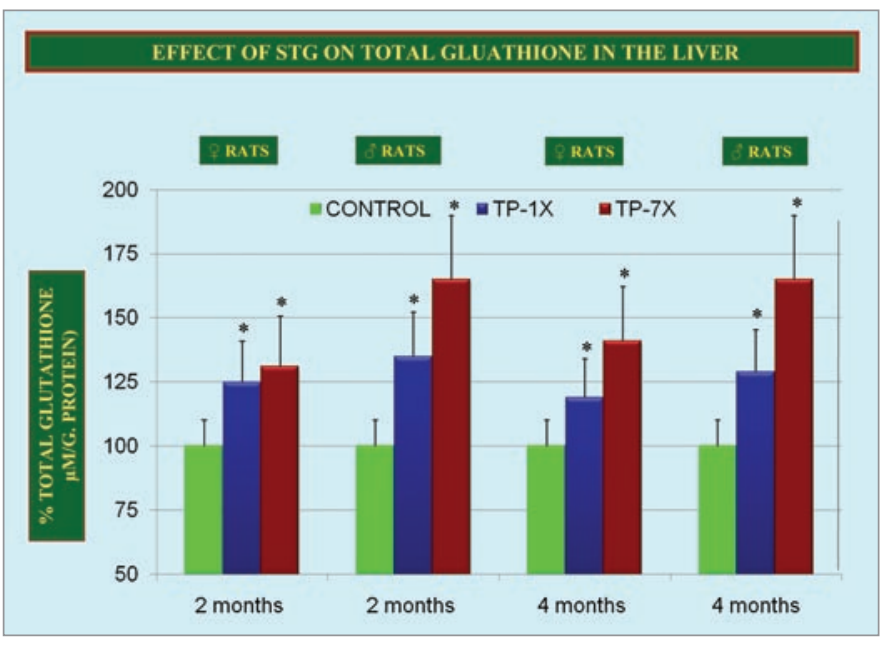

Figure 12. Four months continuous exposure of various doses of STG ( $\mathrm{S}$, sage leaf extract; $\mathrm{T}$, oolong tea extract; $\mathrm{G}$, guarana seed extract) significantly increased total glutathione content in the liver. Although STG exposure showed a characteristic dose-response effect, the overall increase remained within 1.25-1.75 fold. Glutathione content increased in both genders, at both time points by all the doses of STG. Data are expressed as mean $\pm S E M ; n=3$ rats per group. The value is significantly different from vehicle treated control if indicated $\left({ }^{*} p \leq 0.05\right)$.

components of STG to interact with the genome to exhibit such an effect can not be ruled out.

Numerous examples of genomic regulation by nutrients (nutrigenomics) have been published in recent years. Pycnogenol exerts its anticytotoxic property by stimulating glutathione biosynthesis. ${ }^{61}$ Rosemary extract was found to activate an array of detoxification enzymes including glutathione-S-transferase, and $\mathrm{NAD}(\mathrm{P}) \mathrm{H}$ : quinone reductase in the lung, liver and stomach. ${ }^{62}$ Cinnamon and coriander seed extracts increase superoxide dismutase, catalase, GST, glucose-6-phosphate dehydrogenase and glutathione-disulfide reductase activities in the liver. ${ }^{63}$ Fisetin, galangin, quercetin, kaempferol and genistein exhibit potent non-competitive inhibition of sulfotransferase $1 \mathrm{~A} 1 .^{64}$ Various phytochemicals are inducers of CYP450-dependent drug metabolism, whereas some others are potent inhibitors. ${ }^{65-68}$ The impact on the CYP450 system is extremely important from a clinical perspective since co-exposure to these entities along with selected drugs can significantly influence the therapeutic outcome of a drug. Conversely, some drugs may adversely affect biochemical pathways normally under the influence of dietary phytochemicals, resulting in unwanted effects. Examples include the ability of several phytochemicals to interfere with the cell cycle regulatory elements (carcinogen bio-activation, angiogenesis and inflammation) and cancer signaling pathways. ${ }^{72}$ All these reports strongly suggest abilities of phytochemicals to interact with the genome and influence the cell globally.

Since the late 1990s, our laboratory has conducted mechanistic experiments investigating the anti-toxic, anti-cancer, anti-apoptotic and anti-necrotic properties of grape seed proanthocyanidin extract, quercetin, rutin, hesperitin and Momordica charantia and Ocimum sanctum extracts in in vivo models and has elucidated unique organoprotective pathways when these phytochemicals act alone or in combination.-9 Protection of the genomic integrity is one of the most aggressively pursued goal of a cell. Flawed genomic machinery invariably leads to deregulated metabolism. In order to verify the integrity of the genome in all the three vital organs under the influence of STG, total cellular DNA fragmentation assays were performed (Figs. 15-17). Results indicate that STG did not cause genomic injury or any type of genomic instability. The lack of DNA damage (fragmentation) does not tell us whether the large increases in SOD and GPx activities observed in this study in response to STG are due to a genetically-driven induction of new enzymes or an increase in enzyme activities. Nevertheless, this outcome is generally considered beneficial for the organism. Furthermore, both oolong tea extract ${ }^{28,29}$ and sage extract ${ }^{17}$ have been shown to inhibit DNA damage, supporting the results of this study with STG. Oxidative-stress mediated genomic injury and its prevention in phytochemical pre-exposed liver, kidneys and heart has already been reported. ${ }^{7,851}$

In addition to all these parameters, histopathological diagnosis of H\&E and PAS-stained organ sections clearly mirrored the serum chemistry changes, and strongly correlated with some of the biochemical parameters. Gross tissue morphology indirectly reflected untainted metabolic status in all the three organs. Representative sections exposed to the $7 \mathrm{x}$ dose of STG are shown (Figs. 18-20; Tables 1 and 2). Organ sections from control or STG-exposed animals resembled each other with unperturbed tissue architecture. Multiple sections were thoroughly examined to rule the artifactual changes that may have resulted due to tissue processing. Uniform stain intensity reflected health of the cells and indirectly discerned intactness of the intracellular organelles. Nuclear, cytoplasmic and outer boundaries of the hepatocytes were intact. A close examination of kidney sections disclosed normal features of proximal tubular cells, distal tubular cells 
and glomerular apparatus. Examination of heart sections showed normal skeletal muscle fibers, normal intercalated discs and connective tissue, normal nuclei and scattered fibrocytes. None of the areas in any of the target organs revealed the presence of any inflammatory cells, indicating the absence of any inflammation. Apoptotic cells were rarely found in normal or STG-exposed tissues. All these features clearly established the safety of STG. The general health of the animals was another indicator which was closely monitored during the entire study. Control and STGexposed animals did not show any signs of illness.

In conclusion, 4-month exposure of male and female rats to STG dramatically enhanced antioxidant power in the absence of any genomic injury to the liver, heart and kidneys. Significant changes in antioxidant components indirectly disclosed absorption, biodistribution and bioavailability of STG at least in these three organs and liver showed the best response. Although STG exposure did not drastically reduce weight gain, it did help maintain healthy body weight coupled with a robust antioxidant capacity of the vital target organs.

\section{Materials and Methods}

Animals and animal housing conditions. All experiments were conducted within GLP guidelines. Adult male and female Fisher-344 rats were obtained from NCI, Frederick, MD, and given access to lab chow (Purina) and tap water ad libitum. All animals were allowed to acclimate in an environment of controlled temperature $\left(22-25^{\circ} \mathrm{C}\right)$, humidity and light/dark cycle in the Long Island University animal facility for two weeks prior to initiating the study. All cages were examined several times everyday. Body weights of the animals were recorded once every week to monitor growth. All animal procedures received prior approval by the Institutional IACUC and met or exceeded current local/state/federal standards.

Animal treatments. Animals in this study were divided into three groups. Group-1: Control; received regular rat chow (AIN-76 base diet). Group-2: 1X STG diet: received chow premixed with 1X human equivalent of STG (Average human considered as $70 \mathrm{~kg}$; $192 \mathrm{mg}$ of STG per kg). Group-3: 7X STG diet, received chow premixed with $7 \mathrm{X}$ human equivalent of STG. Pre-formulated STG-vitamin mixture in the form of a powder (ThermoPlus) was supplied by AdvoCare Nutritionals (Carrolton, TX).

STG exposure was achieved as follows. STG in powdered form was supplied to the diet manufacturer. Pre-calculated amounts of STG powder (192 mg STG/kg) were mixed with the AIN-76 base diet powder in order to achieve an Average Daily Intake of STG (equivalent to a $70 \mathrm{~kg}$ human). Control and STG-mixed base diet powders were re-pelleted in identical form (approximately 1 inch pellets) which was provided to the animals ad libitum. Pellets were stored at $4-8^{\circ} \mathrm{C}$ as recommended by the manufacturers of the chow and STG system. This diet provided identical calories and continuous STG exposure during each feeding throughout the experimental period.

Randomly sorted animals ( $\mathrm{n}=3$ per group) were sacrificed by decapitation at 0,2 and 4 months. Blood was collected for

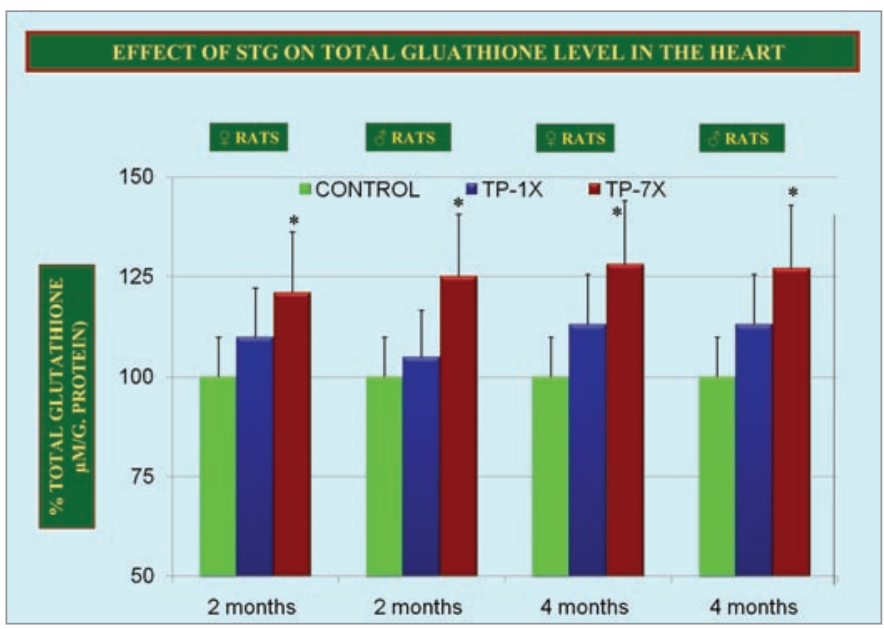

Figure 13. Four months continuous exposure of various doses of STG increased total glutathione content in the heart, although not remarkably. STG showed a characteristic dose-response effect but the overall increase remained below 1.25 fold in both genders at both time points. Data are expressed as mean $\pm S E M ; n=3$ rats per group. The value is significantly different from vehicle treated control if indicated $\left({ }^{*} p \leq 0.05\right)$.

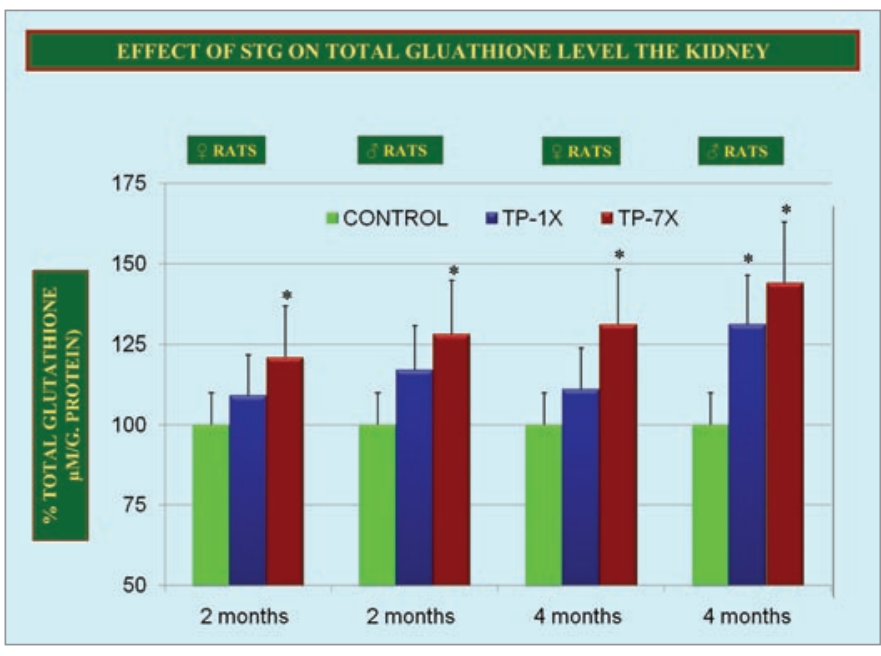

Figure 14. Four months continuous exposure of various doses of STG increased total glutathione content in kidneys, although not remarkably. STG exposure showed a characteristic dose-response effect but the overall increase remained below 1.25 -fold in both genders at both time points. Data are expressed as mean $\pm S E M ; n=3$ rats per group. The value is significantly different from vehicle treated control if indicated $\left(^{*} \mathrm{p} \leq 0.05\right)$.

serum chemistry analysis to indirectly monitor the functioning of the vital organs. Brain, heart, kidneys, spleen, duodenum, lung and liver were collected, sectioned and the tissues were preserved in $10 \%$ buffered formalin for histopathology. Tissues were processed at Charles River Laboratories, MD.

Serum chemistry and tissue biochemistry. Serum chemistry (enzyme, lipid, carbohydrate, electrolyte profiles) analyses were performed at a State and FDA certified diagnostic laboratory approved to perform and report human data. Serum samples 

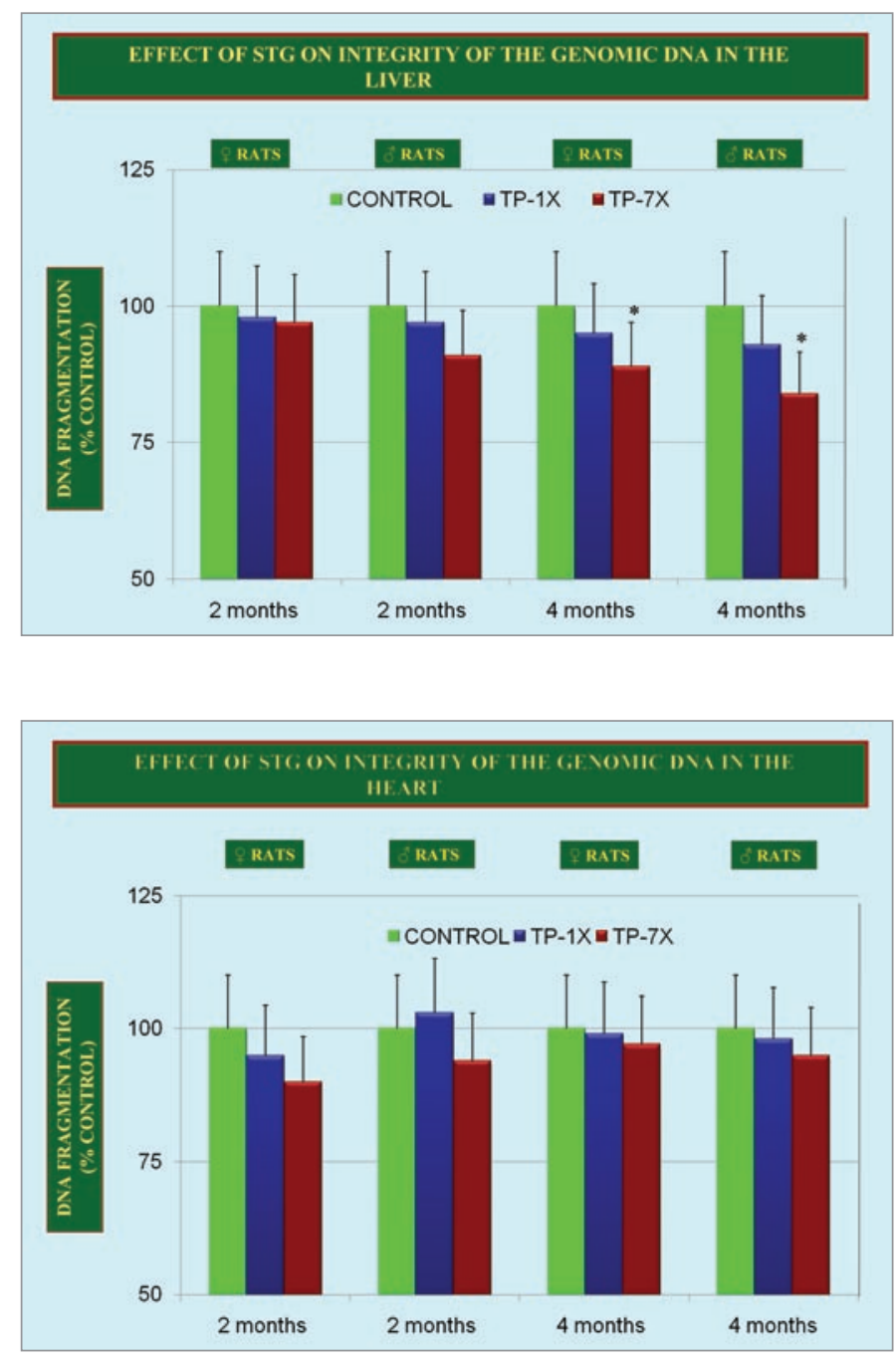

Figure 16. Four months exposure of various doses of STG showed no deleterious effect on integrity of the genomic DNA in the heart. Overall, $\%$ fragmentation was lower in STG exposed hearts compared to the control. DNA fragmentation was quantitated by differential centrifugation, sedimentation and reaction with Burton's reagent. Data are expressed as mean $\pm S E M ; n=3$ rats per group. The value is significantly different from vehicle treated control if indicated $\left({ }^{*} p \leq 0.05\right)$.

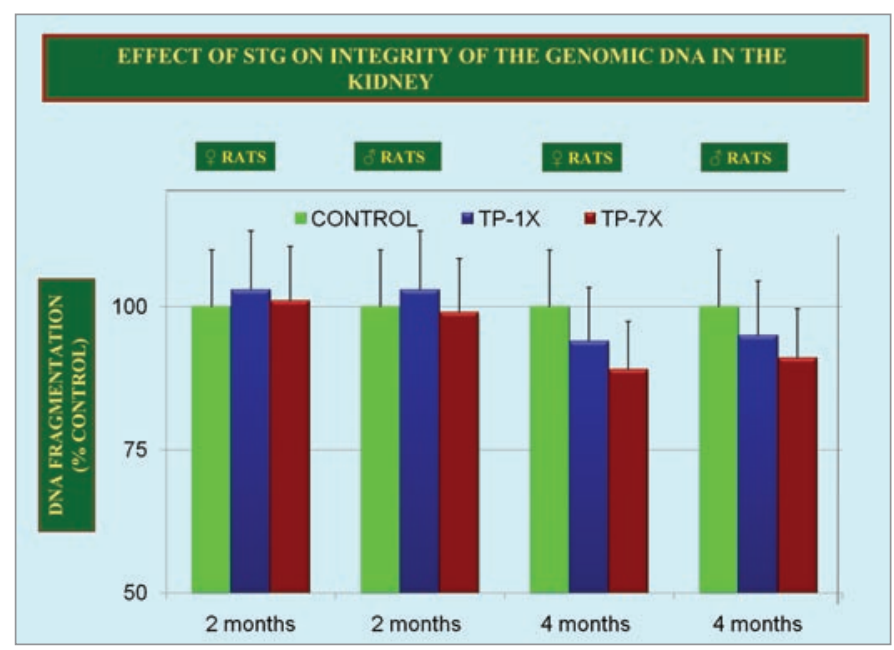

Figure 15. Four months exposure of various doses of STG (S, sage leaf extract; $T$, oolong tea extract; $G$, guarana seed extract) slightly decreased the liver DNA fragmentation from the baseline levels in both genders at 4 months. Fragmentation was quantitated by differential centrifugation, sedimentation and reaction with Burton's reagent. Fragmented DNA was calculated based on \% low molecular weight DNA in the supernatant compared to total DNA (\% fragmented in the soup + intact DNA in the pellet) in a given sample. Besides the degree of genomic injury, DNA fragmentation roughly predicts $\%$ cells undergoing apoptosis. Data are expressed as mean $\pm \mathrm{SEM} ; \mathrm{n}=3$ rats per group. The value is significantly different from vehicle treated control if indicated $\left({ }^{*} \mathrm{p} \leq 0.05\right)$.

were collected and kept frozen at $-70^{\circ} \mathrm{C}$ for delivery in liquid nitrogen to the diagnostic laboratory (Bio-Medical Laboratories, East Brunswick, NJ). Tissue biochemistry (assessment of oxidative stress, DNA fragmentation) were conducted following the methods of Ray et al. (2006) and Cayman Chemical enzyme assay kits were employed to determine superoxide dismutase (SOD) activity, glutathione peroxidase (GPx) activity and total tissue glutathione contents.

Superoxide dismutase assay/SOD activity (cayman chemical kit\# 706002). SOD activity was assessed by measuring the dismutation of superoxide radicals generated by xanthine oxidase-hypoxanthine system based on a reaction sequence: $\mathbf{2 O}_{2}$ $+2 \mathrm{H}^{+}+\mathrm{SOD} \rightarrow \mathrm{H}_{2} \mathrm{O}_{2}+\mathrm{O}_{2}$ and formation of a formazan dye from a tetrazolium salt. Purified SOD was used to plot a standard curve in order to accurately quantify the activity of all three types of SOD $\left(\mathrm{Cu} / \mathrm{Zn}^{-}, \mathrm{Mn}^{-}\right.$and $\left.\mathrm{Fe}^{-} \mathrm{SOD}\right)$. One unit of SOD is defined as the amount of enzyme needed to exhibit 50\% dismutation of $2 \mathrm{O}_{2}{ }^{-}$radical. The SOD stock solutions $(0-200 \mu \mathrm{L})$ for SOD standard activities $(0-0.25 \mathrm{U} / \mathrm{ml})$ contained $20 \mu \mathrm{L}$ of $\mathrm{Cu} /$ $\mathrm{Zn}$-SOD from bovine erythrocytes dissolved in $1.98 \mathrm{ml}$ of 50 $\mathrm{mM}$ Tris- $\mathrm{HCl}, \mathrm{pH}$ 8.0. Frozen organs (one-half kidney; one-half heart, and ca. $100 \mathrm{mg}$ liver) were washed with cold HEPES buffer, blotted dry on a filter paper and weighed. Tissues were homogenized in a cold glass with a teflon pestle using a pre-chilled buffer (20 mM HEPES, $1 \mathrm{mM}$ EGTA, $210 \mathrm{mM}$ mannitol, $70 \mathrm{mM}$ sucrose per gram tissue) and centrifuged at 5,000 $\mathrm{xg}$ for $10 \mathrm{~min}$ at $4^{\circ} \mathrm{C}$. Sample background was deducted by omitting xanthine oxidase. Total SOD levels were calculated based on absorbance at $450 \mathrm{~nm}$ according to the formula in the kits and expressed as units per gram protein derived from units $/ \mathrm{ml}$ values. All samples were assayed in triplicate and expressed as percent control.

Glutathione peroxidase activity (cayman chemical kit\# 703102; GPx: EC\# 1.11.1.9). Tissues (one-half kidney; one-half heart, and ca. $100 \mathrm{mg}$ liver) were briefly washed with pre-chilled phosphate buffer ( $\mathrm{pH} 7.4$ ) and homogenized in cold Tris buffer

\footnotetext{
Figure 17. Four months exposure of various doses of STG showed no adverse effect on integrity of the genomic DNA in kidneys. Overall, \% fragmentation was lower in STG exposed kidneys compared to the control. DNA fragmentation was quantitated by differential centrifugation, sedimentation and reaction with Burton's reagent. Data are expressed as mean $\pm S E M ; n=3$ rats per group. The value is significantly different from vehicle treated control if indicated $\left({ }^{*} p \leq 0.05\right)$.
} 


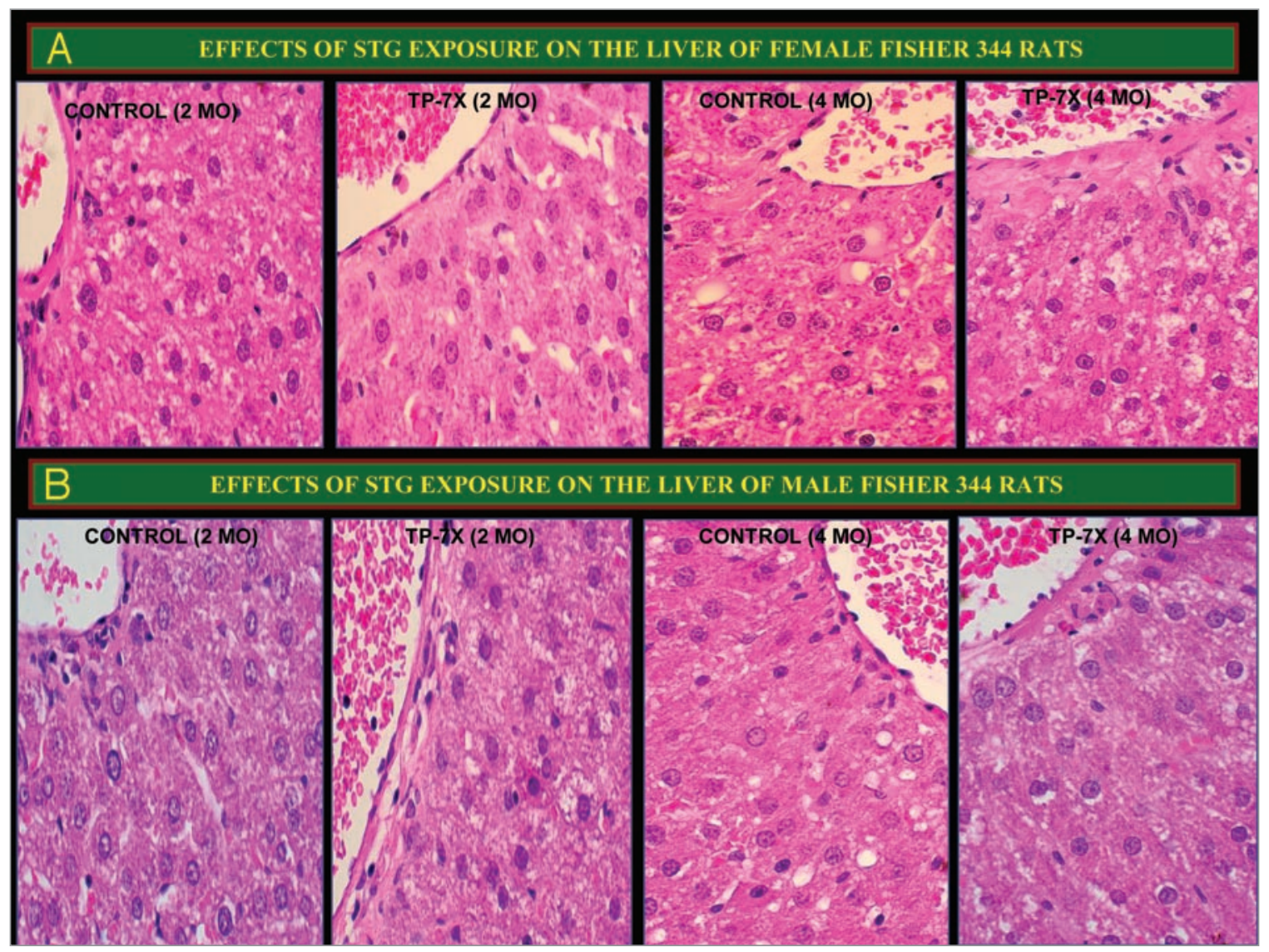

Figure 18. Brightfield photomicrographs (40X) of H\&E-stained representative sections from the largest lobe of the variously treated rat livers. Photomicrographs show effects of up to 4 months exposure of $7 X$ dose (high dose) of STG (S, sage leaf extract; T, oolong tea extract; G, guarana seed extract) on the liver histopathology. Most cells discerned intact nucleus and confluent intracellular compartment. STG exposed tissue sections very closely resembled control livers. Analysis of several representative sections from both 1X and 7X STG exposed livers revealed no architectural alterations.

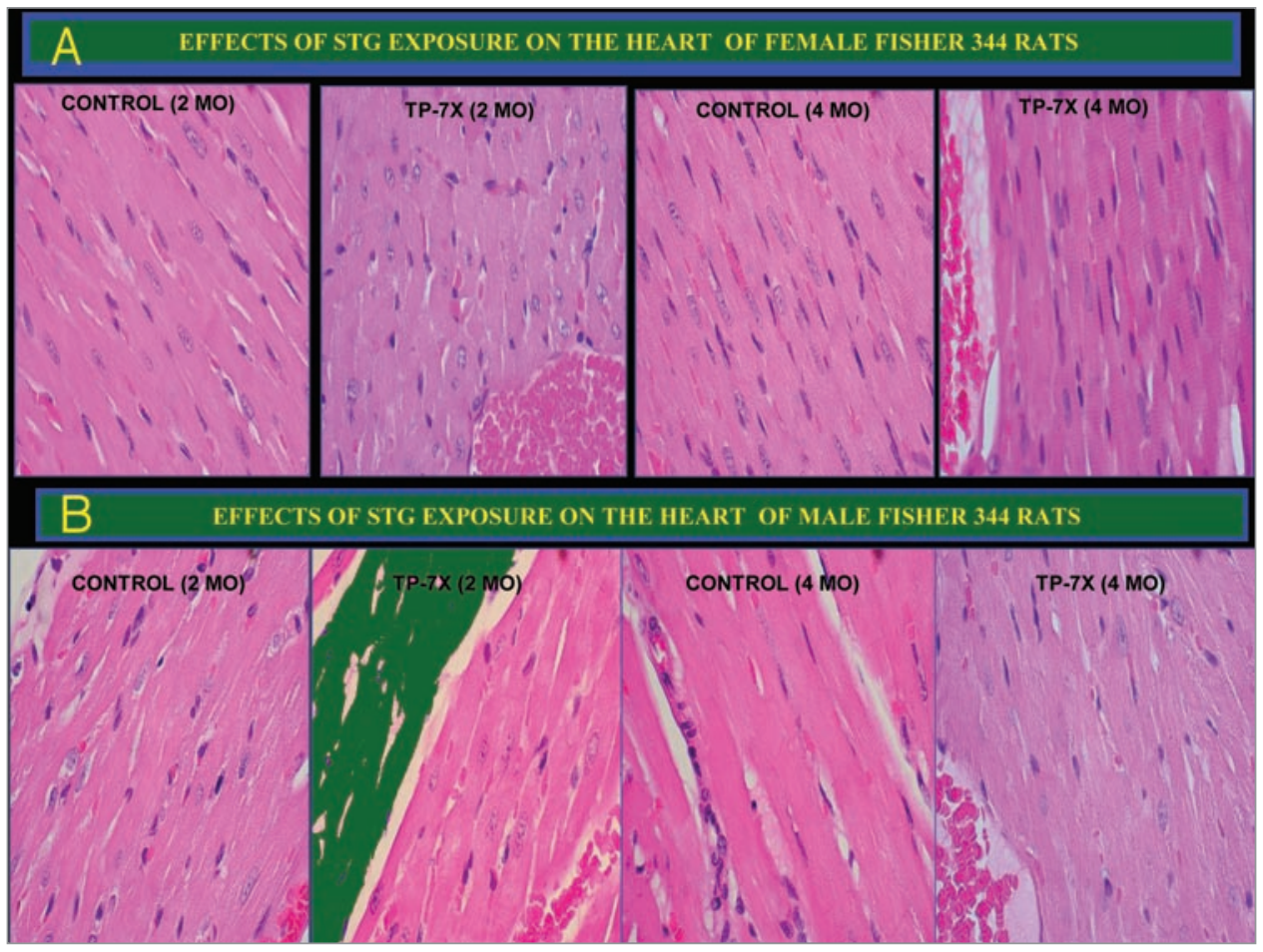


Figure 19 (see previous page). Brightfield photomicrographs (40X) of H\&E-stained representative sections from variously treated rat hearts. Photomicrographs show effects of up to 4 months exposure of 7x dose (high dose) of STG on the cardiac histopathology. Cardiac myocytes displayed normal nuclear and myofibrillar features. Most areas remained devoid of any inflammatory cells. Analysis of several representative sections from both $1 \mathrm{X}$ and 7 X STG exposed hearts revealed no architectural alterations.

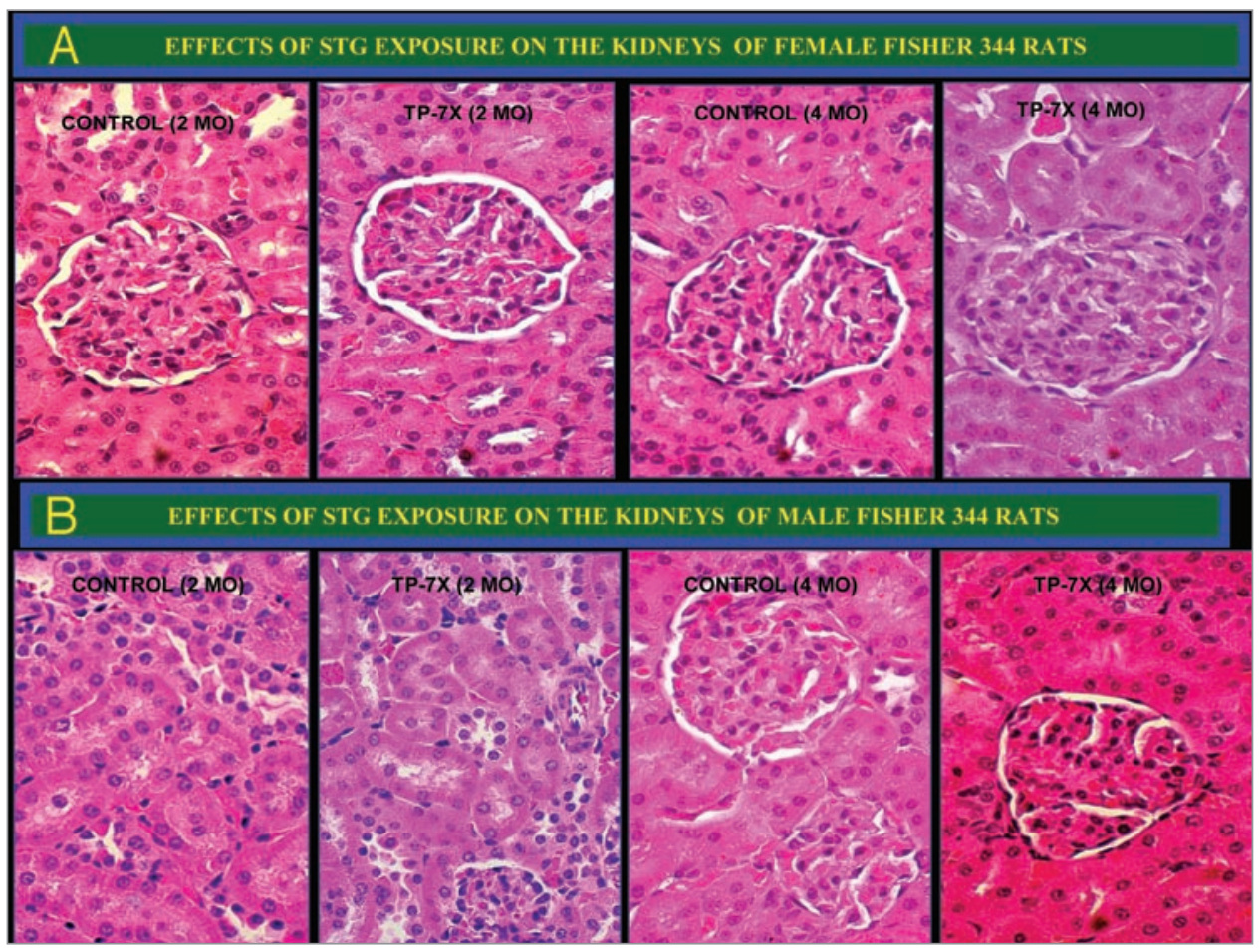

Figure 20. Brightfield photomicrographs (40X) of H\&E-stained representative sections from variously treated rat kidneys. Photomicrographs show effects of up to 4 months exposure of 7X dose (high dose) of STG on the kidney histopathology. Most vital kidney structures (glomerulus, proximal and distal tubular cells, brush border zones and cortex areas) remained normal after STG exposure. Analysis of several representative sections from both $1 \mathrm{X}$ and $7 \mathrm{X}$ STG exposed kidneys revealed no architectural alterations.

(50 mM TRIS-HCl; 5 mM EDTA, 1 mM DTT, pH 7.5). The homogenate was centrifuged at $10,000 \mathrm{xg}$ for $15 \mathrm{~min}$ at $4^{\circ} \mathrm{C}$, and the final supernatant was used for the assay. The GPx assay kit indirectly measures GPx activity by a coupled reaction with glutathione reductase (GR). Oxidized glutathione (GSSG), produced upon reduction of an organic hydroperoxide by GPx, and is recycled to its reduced state by GR and NADPH [(1) R-O$\mathrm{O}-\mathrm{H}+2 \mathrm{GSH} \rightarrow \mathrm{GPx} \rightarrow \mathrm{R}-\mathrm{O}-\mathrm{H}+\mathrm{GSSG}+\mathrm{H}_{2} \mathrm{O}$; (2) GSSG $+\mathrm{NADPH} \rightarrow \mathrm{GR} \rightarrow 2 \mathrm{GSH}+\mathrm{NADP}^{+}$. The oxidation of NADPH to $\mathrm{NADP}^{+}$is accompanied by a decrease in absorbance at $340 \mathrm{~nm}$. The rate of decrease in the absorbance at $340 \mathrm{~nm}$ is directly proportional to the GPx activity in the sample. This assay measured all of the glutathione-dependent peroxidases in tissue homogenates and is expressed as control $\mathrm{nmol} / \mathrm{min} / \mathrm{ml}$. Final data is expressed as percent control.

Total glutathione assay (GSH + GSSG; cayman chemical kit\# 703002). This assay kit utilizes a carefully optimized enzymatic recycling method for the quantification of glutathione. Glutathione reductase (GR) reduces oxidized glutathione (GSSG) to reduced glutathione (GSH). GSH is easily oxidized to the disulfide dimer GSSG. The sulfhydryl group of GSH reacts with DTNB (5,5'-dithiobis-2-nitrobenzoic acid, Ellman's reagent) to produce a yellow colored 5-thio-2-nitrobenzoic acid (TNB) that absorbs at 405 or $414 \mathrm{~nm}$. The rate of TNB production is directly proportional to the concentration of glutathione in the sample. The measurement of the absorbance of TNB at 405 or $414 \mathrm{~nm}$ provides an accurate estimation of glutathione in the sample. Frozen organs (one-half kidney; one-half heart, and ca.100 mg liver) were washed with cold 1x phosphate buffered saline (PBS), blotted dry on a filter paper and weighed. Ice-cold $5 \%(\mathrm{w} / \mathrm{v})$ metaphosphoric acid $(20 \mathrm{ml} / \mathrm{g}$ tissue) was added and the tissues were homogenized using a cold glass with a Teflon pestle. Homogenates were centrifuged at $14,000 \mathrm{xg}$ for $15 \mathrm{~min}$ at $4^{\circ} \mathrm{C}$. Supernatants were used to assay total glutathione. Level was expressed in units per gram protein. All samples were assayed in triplicate. Total glutathione is expressed as \%control nmol/ gram liver.

Determination of tissue malondialdehyde (MDA). Levels of oxidative stress and its consequence lipid peroxidation was indirectly measured by malondialdehyde (MDA) concentrations in tissue homogenates by TBARS (thiobarbituric acid reactive substances) reaction using the method of Ray et al. This is a spectrophotometric method designed to detect pink-colored TBA-MDA chromogen at $532 \mathrm{~nm}$. MDA was used as the standard. Frozen 
tissue homogenates (at $-70^{\circ} \mathrm{C}$ prepared in $\mathrm{PBS}$ ) were treated with BHT used to determine levels of oxidative stress. The values are expressed as nmol MDA/g liver and presented as percent control changes. Triplicate assays were performed in each measurement and the average values were obtained from each individual tissue sample. $^{73}$

Analysis of genomic DNA fragmentation. DNA damage was quantitated in organ homogenates $(n=4$ or more) from each treatment group. ${ }^{74-76}$ To measure DNA fragmentation by spectrophotometry, the whole frozen tissues were homogenized in chilled lysis buffer $(10 \mathrm{mM}$ Tris- $\mathrm{HCl}, 20 \mathrm{mM}$ EDTA, $0.5 \%$ Triton X-100, $\mathrm{pH}$ 8.0). Homogenates were then centrifuged at $27,000 \mathrm{xg}$ for $20 \mathrm{~min}$ to separate intact chromatin in the pellet from fragmented DNA in the supernatant. Pellets were resuspended in $0.5 \mathrm{~N}$ perchloric acid and supernatants were treated with concentrated perchloric acid to reach a final concentration of $0.5 \mathrm{~N}$. All the samples were boiled at $90^{\circ} \mathrm{C}$ for $15 \mathrm{~min}$ and centrifuged at $8,000 \mathrm{xg}$ for $10 \mathrm{~min}$ to co-precipitate protein along with other debris. Resulting supernatants were then treated with diphenylamine for $16-20 \mathrm{~h}$ at room temperature to develop color. DNA standards (59-29-hexose-monophosphate) at various concentrations were also prepared and treated with diphenylamine. Absorbances for samples and standard solutions were measured at 1,600 nm with a Beckman DU 640 spectrophotometer. A standard concentration vs. absorbance curve was generated and sample DNA levels were extrapolated from this standard curve. DNA fragmentation in control samples were treated as 100\% fragmentation based on a formula [(frag. DNA)/(frag. DNA +

\section{References}

1. Siddiqui IA, Afaq F, Adhami VM, Ahmad N, Mukhtar $\mathrm{H}$. Antioxidants of the beverage tea in promotion of human health. Antioxid Redox Signal 2004; 6:571-82.

2. Iuvone T, De Filippis D, Esposito G, D’Amico A, Izzo AA. The spice sage and its active ingredient rosmarinic acid protect PC12 cells from amyloid-beta peptideinduced neurotoxicity. J Pharmacol Exp Ther 2006; 317:1143-9.

3. Lahaie-Collins V, Bournival J, Plouffe M, Carange J, Martinoli MG. Sesamin modulates tyrosine hydroxylase, superoxide dismutase, catalase, inducible NO synthase and interleukin- 6 expression in dopaminergic cells under MPP-induced oxidative stress. Oxid Med Cell Longev 2008; 1:54-62.

4. Ray SD, Bagchi D. Roles of Polyphenols, Flavonoids and Oligomeric Proanthocyanidins in Cancer Chemoprevention, in Preuss HG, Bagchi D, (Eds.), Phytopharmaceuticals in cancer chemoprevention, CRC Press USA 2004; 311-48.

5. Ray SD, Parikh H, Bagchi D. Proanthocyanidin exposure to $\mathrm{B} 6 \mathrm{C} 3 \mathrm{~F} 1$ mice significantly attenuates dimethylnitrosamine-induced liver tumor induction and mortality by differentially modulating programmed and unprogrammed cell deaths. Mut Res 2005a; 579:81-106.

6. Ray SD, Kumar MA, Bagchi D. A novel IH636 grape seed extract increases in vivo $\mathrm{Bcl}-\mathrm{X}_{\mathrm{L}}$ expression and prevents acetaminophen-induced programmed and unprogrammed cell death in mouse liver. Arch Biochem Biophys 1999; 369:42-58.

7. Ray SD, Patel D, Wong V, et al. In vivo protection of DNA damage associated apoptotic and necrotic cell deaths during acetaminophen-induced nephrotoxicity, amiodarone-induced lung toxicity and doxorubicininduced cardiotoxicity by a novel IH636 grape seed proanthocyanidin extract. Res Commu Mol Pathol Pharmacol 2000; 107:137-66. 2000; 107:105-28. intact DNA)]. DNA appearing in the supernatant was divided by the total DNA to generate percentage fragmentation. Treatment effects were reported as percent control fragmentation.

Histological evaluation. A board certified CRL laboratory veterinarian read all the final $\mathrm{H} \& \mathrm{E} / \mathrm{PAS}$ stained slides and provided a report (regulatory spirit). Upon receipt of the report, one of us (SR) examined all the slides of all the organs and recorded the details. Characteristics of apoptosis, necrosis and apocrosis were determined based on our previously published procedures. ${ }^{55-58}$ Histopathology pictures were taken using a Carl-Zeiss brightfield microscope. ${ }^{56}$

Statistical analysis. Results are presented as mean \pm SEM unless otherwise indicated. Data were analyzed for significance ( $\mathrm{p}<0.05)$ using analysis of variance (ANOVA) followed by Fisher PLSD test (Stat View II, Abacus Concepts Inc., Berkeley, California). Differences were attributed to treatment rather than chance variance when $\mathrm{p}<0.05$.

\section{Acknowledgements}

Funding for this study was received from AdvoCare International, Carrollton, TX. E.B., D.Z., P.P. and V.J. received graduate assistantships from the Division of Pharmaceutical Sciences of AMS College of Pharmacy.

\section{Conflicts of interest}

One of the authors, S.J.S., Dean Emeritus, Creighton University College of Pharmacy and Allied Health Professions is a part-time $\mathrm{R} \& \mathrm{D}$ consultant of Advocare.
8. Ray SD, Wong V, Rinkovsky A, et al. Unique organoprotective properties of a novel IH636 grape seed proanthocyanidin extract on cadmium chlorideinduced nephrotoxicity, dimethylnitrosamine (DMN)induced splenotoxicity and MOCAP-induced neurotoxicity in mice. Res Commu Mol Pathol Pharmacol

9. Ray SD, Patel N, Shah N, Nagori A, Naqvi A, Stohs SJ. Pre-exposure to a novel nutritional mixture containing a series of phytochemicals prevents acetaminopheninduced programmed and unprogrammed cell deaths by enhancing $\mathrm{BCL}-\mathrm{X}_{\mathrm{L}}$ expression and minimizing oxidative stress in the liver. Mol Cell Biochem 2006; 293:119-36.

10. Ray S, Phadke S, Patel C, Hackman RM, Stohs S. Short-term and long-term in vivo exposure to an ephedra- and caffeine-containing metabolic nutrition system does not induce cardiotoxicity in $\mathrm{B} 6 \mathrm{C} 3 \mathrm{~F} 1$ mice. Arch Toxicol 2005b; 79:330-40

11. Parmar M, Imail S, Ray SD. A Triple bioflavonoid mixture modulates pro- and anti-apoptotic gene expression during streptozocin (STZ)-induced oxidative stress in the mouse liver. The Toxicologist 2008; 97:769.

12. Ray SD, Parmar M, Syed I, Rathod J, Zinkovsky D, Bulku E, et al. Long term exposure effect of a unique metabolic nutrition system containing a diverse group of phytochemicals on serum chemistry and genomic and non-genomic changes in the liver of female B6C3F1 mice. Phytother Res 2008; 22:458-71.

13. Ray S, Bagchi D, Lim PM, Bagchi M, Gross SM, Kothari SC, et al. Acute and long-term safety evaluation of a novel IH636 grape seed proanthocyanidin extract. Res Commun Mol Pathol Pharmacol 2001; 109:165-97.

14. Chung JH, Han JH, Hwang EJ, Seo JY, Cho KH, Kim KH, et al. Dual mechanisms of green tea extract (EGCG)-induced cell survival in human epidermal keratinocytes. The FASEB J 2003; 17:1913-5.
15. Bloomer RJ, Fisher-Wellman KH. Systemic oxidative stress is increased to a greater degree in young, obese women following consumption of a high fat meal. Oxid Med Cell Longev 2009; 2:19-25.

16. Luvone T, De Filippis D, Esposito G, D’Amico A, Izzo AA. The spice sage and its active ingredient rosmarinic acid protect PC12 cells from amyloid-beta peptideinduced neurotoxicity. J Pharmacol Exp Therapeu 2006; 317:1143-9.

17. Aherne SA, O'Brien NM. Effects of plant extracts on antioxidant status and oxidant-induced stress in Caco-2 cells. Br J Nutr 2007; 97:321-8.

18. Lima CF, Andrade PB, Seabra RM, Fernandes-Ferreira M, Pereira-Wilson C. The drinking of a Salvia officinalis infusion improves liver antioxidant status in mice and rabbits. J Ethnopharmacol 2005; 97:383-9.

19. Ninomiya K, Matsuda H, Shimoda H, Nishida N, Kasajima N, Yoshino T, et al. Carnosic acid, a new class of lipid absorption inhibitor from sage. Bioorg Med Chem Lett 2004; 14:1943-6.

20. Kennedy DO, Scholey AB. The psychopharmacology of European herbs with cognition-enhancing properties. Curr Pharm Des 2006; 12:4613-23.

21. Clearfield M. Effects of lipid-lowering therapy on coronary heart disease in older patients: the SAGE study. Curr Atheroscler Rep 2008; 10:5-6.

22. Yu YM, Lin HC, Chang WC. Carnosic acid prevents the migration of human aortic smooth muscle cells by inhibiting the activation and expression of matrix metalloproteinase-9. British Journal of Nutrition 2008; 100:731-8.

23. Shimada K, Kawarabayashi T, Tanaka A, Fukuda D, Nakamura Y, Yoshiyama M, et al. Oolong tea increases plasma adiponectin levels and low-density lipoprotein particle size in patients with coronary artery disease. Diabetes Res Clin Pract 2004; 65:227-34.

24. Cabrera C, Artacho R, Giménez R. Beneficial effects of green tea-a review. J Am Coll Nutr 2006; 25:79-99. 
25. Cheng TO. All teas are not created equal: the Chinese green tea and cardiovascular health. Int J Cardiol 2006; 108:301-8.

26. Rumpler W, Seale J, Clevidence B, Judd J, Wiley E, Yamamoto S, et al. Oolong Tea Increases Metabolic Rate and Fat Oxidation in Men. J Nutr 2000; 131:2848-52.

27. Kurihara H, Fukami H, Asami S, Toyoda Y, Nakai M, Shibata $\mathrm{H}$, et al. Effect of oolong tea on plasma antioxidative capacity in mice loaded with restraint stress assessed using the oxygen radical absorbance capacity (ORAC) assay. Biol Pharm Bull 2004; 27:1093-8.

28. Yen GC, Ju JW, Wu CH. Modulation of tea and tea polyphenols on benzo(a)pyrene-induced DNA damage in Chang liver cells. Free Rad Res 2004; 38:193-200.

29. Zhu QY, Hackman RM, Ensunsa JL, Holt RR, Keen CL. Antioxidant activities of oolong tea. J Agric Food Chem 2002; 50:6929-34.

30. Lin JK, Lin-Shiau SY. Mechanisms of hypolipidemic and anti-obesity effects of tea and tea polyphenols. Mol Nutr Food Res 2006; 50:211-7.

31. Han LK, Takaku T, Li J, Kimura Y, Okuda H. Antiobesity action of oolong tea. Int J Obes Relat Metab Disord 1999; 23:98-105.

32. He RR, Chen L, Lin BH, Matsui Y, Yao XS, Kurihara $H$. Beneficial effects of oolong tea consumption on diet-induced overweight and obese subjects. Chin J Integr Med 2009; 15:34-41.

33. Nagao T, Komine Y, Soga S, Meguro S, Hase T, Tanaka $\mathrm{Y}$, et al. Ingestion of a tea rich in catechins leads to a reduction in body fat and malondialdehyde-modified LDL in men. Am J Clin Nutr 2005; 81:122-9.

34. Roberts AT, de Jonge-Levitan L, Parker CC, Greenway F. The effect of an herbal supplement containing black tea and caffeine on metabolic parameters in humans. Altern Med Rev 2005; 10:321-5.

35. Hashimoto T, Goto M, Sakakibara H, Oi N, Okamoto M, Kanazawa K. Yellow tea is more potent than other types of tea in suppressing liver toxicity induced by carbon tetrachloride in rats. Phytother Res 2007; 21:668-70.

36. Tanida M, Tsuruoka N, Shen J, Kiso Y, Nagai K. Effects of oolong tea on renal sympathetic nerve activity and spontaneous hypertension in rats. Metabolism 2008; 57:526-34.

37. Mineharu Y, Koizumi A, Wada Y, Iso H, Watanabe Y, Date C, et al. Coffee, green tea, black tea and oolong tea consumption and risk of mortality from cardiovascular disease in Japanese men and women. J Epidemiol Community Health 2009; In press.

38. Lima W, Carnevali L, Eder R, Costa Rosa L, Bacchi L, Seelaender M. Lipid metabolism in trained rats: Effect of guarana (Mart.) supplementation. Clin Nutr 2004; 24:1019-28.

39. Basile A, Ferrara L, Pezzo MD, Mele G, Sorbo S, Bassi P, et al. Antibacterial and antioxidant activities of ethanol extract from Paullinia cupana Mart. J Ethnopharmacol 2005; 102:32-6.

40. Yamaguti-Sasaki E, Ito LA, Canteli VC, Ushirobira TM, Ueda-Nakamura T, Dias Filho BP, et al. Antioxidant capacity and in vitro prevention of dental plaque formation by extracts and condensed tannins of Paullinia cupana. Molecules 2007; 12:1950-63.

41. Mattei R, Dias RF, Espínola EB, Carlini EA, Barros SB. Guarana (Paullinia cupana): toxic behavioral effects in laboratory animals and antioxidants activity in vitro. J Ethnopharmacol 1998; 60:111-6.

42. Fisher-Wellman K, Bloomer RJ. Oxidative stress and antioxidant defense mechanisms linked to exercises during cardiopulmonary and metabolic disorders. Oxid Med Cell Longev 2009; 2:43-51.
43. Pontieri V, Neto AS, de França Camargo AF, Koike MK, Velasco IT. The herbal drug Catuama reverts and prevents ventricular fibrillation in the isolated rabbit heart. J Electrocardiol 2007; 40:534-8.

44. Majhenic L, Škerget M, Knez Z. Antioxidant and antimicrobial activity of guarana seed extracts. Food Chem 2007; 104:1258-68.

45. Fukushima Y, Ohie T, Yonekawa Y, Yonemoto K, Aizawa H, Mori Y, et al. Coffee and Green Tea as a large source of antioxidant polyphenols in the Japanese population. J Agric Food Chem 2009; 57:1253-9.

46. Komatsu T, Nakamori M, Komatsu K, Hosoda K, Okamura M, Toyama K, et al. Oolong tea increases energy metabolism in Japanese females. J Med Invest 2003; 50:170-5

47. Yang CS, Landau JM. Effects of tea consumption on nutrition and health. J Nutr 2000; 130:2409-12.

48. Kovacs EM, Lejeune MP, Nijs I, Westerterp-Plantenga MS. Effects of green tea on weight maintenance after body-weight loss. Br J Nutr 2004; 91:431-7.

49. Hursel R, Viechtbauer W, Westerterp-Plantenga MS. The effects of green tea on weight loss and weight maintenance: a meta-analysis. Int J Obes 2009; 33:956-61.

50. Juhel C, Armand M, Pafumi Y, Rosier C, Vandermander J, Lairon D. Green tea extract $\left(A R 25^{\circledR}\right)$ inhibits lipolysis of triglycerides in gastric and duodenal medium in vitro. J Nutr Biochem 2000; 11:45-51.

51. Ray SD, Zinkovsky D, Bulku E, Patil B. Prevention of drug-induced programmed and unprogrammed cell death by citrus flavonoids. American Chemical Society publication, Proc. of $228^{\text {th }}$ ACS-Agriculture \& Food section symposium "Beneficial Health Effects of Citrus", Chapter 11, 2006, ACS symposium series publications \#936.

52. Mendes FR. Brazilian plants as possible adaptogens: An ethnopharmacological survey of books edited in Brazil. J Ethnopharmacol 2007; 109:493-500.

53. Opala T, Rzymski P, Pischel I, Wilczak M, Wozniak J. Efficacy of 12 weeks supplementation of a botanical extract-based weight loss formula on body weight, body composition and blood chemistry in healthy, overweight subjects - a randomised double-blind placebo-controlled clinical trial. Eur J Med Res 2006; 11:343-50.

54. Bérubé-Parenta S, Pelletiera C, Doréa J, Tremblaya A. Effects of encapsulated green tea and Guarana extracts containing a mixture of epigallocatechin-3-gallate and caffeine on $24 \mathrm{~h}$ energy expenditure and fat oxidation in men. Br J Nutr 2005; 94:432-6.

55. Stote KS, Baer DJ. Tea consumption may improve biomarkers of insulin sensitivity and risk factors for diabetes. Nutr 2008; 138:1584-8.

56. Stoner GD, Mukhtar H. Polyphenols as cancer chemopreventive agents. J of Cellu Biochem 1995; 59:169-80.

57. Sa' CM, Ramos AA, Azevedo MF, Lima CF, FernandesFerreira M, Pereira-Wilson C. Sage tea drinking improves lipid profile and antioxiodant defences in humans. Int J Mol Sci 2009; 10:3937-50.

58. Ghanem KZ, Ramadan MM, El-massry KF, Ghanem HZ. Effect of Egyptian sage extract on antioxidant activity, hypercholesterolemia and bone calcification in the tibia of rats. J Arab Soc Med Res 2009; 4:9-17.

59. Zupkó I, Hohmann J, Rédei D, Falkay G, Janicsák G, Máthé I. Antioxidant activity of leaves of Salvia species in enzyme-dependent and enzyme-independent systems of lipid peroxidation and their phenolic constituents. Planta Med 2001; 67:366-8.

60. Jimoh FO, Sofidiya MO, Afolayan AJ. Antioxidant properties of the methanol extracts from the leaves of Paullinia pinnata. J Med Food 2007; 10:707-11.
61. Maritim A, Dene BA, Sanders RA, Watkins JB, 3rd. Effects of pycnogenol treatment on oxidative stress in streptozotocin-induced diabetic rats. J Biochem Mol Toxicol 2003; 17:193-9.

62. Singletary KW. Rosemary extract and carnosol stimulate rat liver glutathione-S-transferase and quinone reductase activities. Cancer Lett 1996; 100:139-44.

63. Lampe JW. Spicing up a vegetarian diet: chemopreventive effects of phytochemicals. Am J of Clin Nutr 2003; 78:579-83.

64. Moon YJ, Wang X, Morris ME. Dietary flavonoids: effects on xenobiotic and carcinogen metabolism. Toxicol In Vitro 2005; 20:187-210.

65. Ray SD, Parikh H, Hickey E, Bagchi M, Bagchi D. Differential effects of IH636 grape seed proanthocyanidin extract and a DNA repair modulator 4-aminobenzamide on liver microsomal CYP-4502E1 dependent aniline hydroxylation. Mol Cellu Biochem 2001; 218:27-33.

66. Jancová $\mathrm{P}$, Anzenbacherová E, Papousková $\mathrm{P}$, et al. Silybin is metabolized by cytochrome P450 2C8 in vitro. Drug Metab Dispos 2007; 35:2035-9.

67. Dvorák Z, Vrzal R, Ulrichová J. Silybin and dehydrosilybin inhibit cytochrome P450 1A1 catalytic activity: a study in human keratinocytes and human hepatoma cells. Cell Biol Toxicol 2006; 22:81-90.

68. Zhang FJ, Yang JY, Mou YH, Sun BS, Ping YF, Wang $\mathrm{JM}$, et al. Inhibition of U-87 human glioblastoma cell proliferation and formyl peptide receptor function by oligomer procyanidins (F2) isolated from grape seeds. Chem Biol Int 2009; 179:419-29.

69. Ray SD, Bagchi D. Roles of Polyphenols, Flavonoids and Oligomeric Proanthocyanidins in Cancer Chemoprevention. Preuss HG, Bagchi D, Eds., CRC Press 2005; 311-48.

70. Mertens-Talcott S. Percival, Ellagic acid and quercetin interact synergistically with resveratrol in the induction of apoptosis and cause transient cell cycle arrest in human leukemia cells. Can Lett 2005; 218:141-51.

71. Deep G, Singh RP, Agarwal C, Kroll DJ, Agarwal R. Silymarin and silibinin cause $G_{1}$ and $G_{2}-M$ cell cycle arrest via distinct circuitries in human prostate cancer PC3 cells: a comparison of flavanone silibinin with flavanolignan mixture silymarin. Oncogene 2006; 25:1053-69.

72. Na HK, Surh YJ. Modulation of Nrf2-mediated antioxidant and detoxifying enzyme induction by the green tea polyphenol EGCG, Food Chem. Toxicol 2008; 46:1271-8.

73. Hickey EJ, Raje RR, Reid VE, Gross SM, Ray SD. Diclofenac-Induced in vivo nephrotoxicity may involve oxidative stress mediated massive genomic DNA fragmentation and apoptotic cell death. Free Rad Biol Med 2001; 139-52.

74. Ray SD, Balasubramanian G, Bagchi D, Reddy CS. $\mathrm{Ca}^{2+}$-calmodulin antagonist chlorpromazine and poly(ADP-ribose)polymerase modulators 4-aminobenzamide and nicotinamide influence hepatic expression of BCL- $\mathrm{X}_{\mathrm{L}}$ and $\mathrm{p} 53$ and protect against acetaminophen-induced programmed and unprogrammed cell death in mice. Free Rad Biol Med 2001; 31:277-91.

75. Ray SD, Mumaw VR, Raje RR, Fariss MW. Protection of acetaminophen-induced hepatocellular apoptosis and necrosis by cholesteryl hemisuccinate pretreatments. J Pharm Exp Therapeu 1996; 279:1470-83.

76. Ray SD, Jena N. Hepatotoxic dose of acetaminophen modulates expression of BCL-2, BCL-X(L) and BCL$\mathrm{X}(\mathrm{S})$ during apoptotic and necrotic death of mouse liver cells in vivo. Arch Toxicol 2000; 73:594-606. 


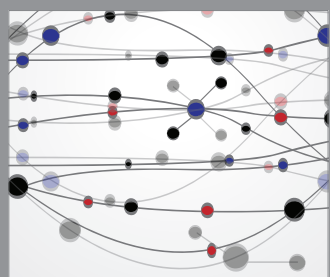

The Scientific World Journal
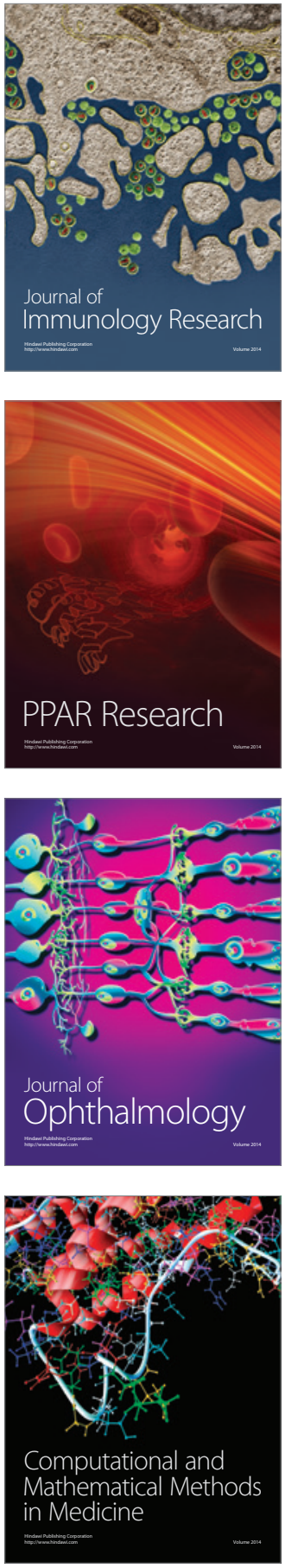

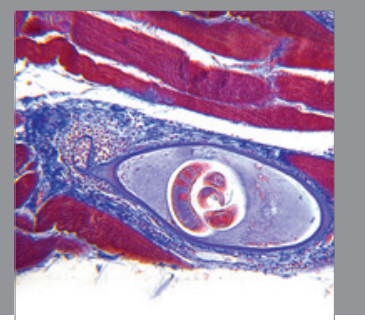

Gastroenterology

Research and Practice
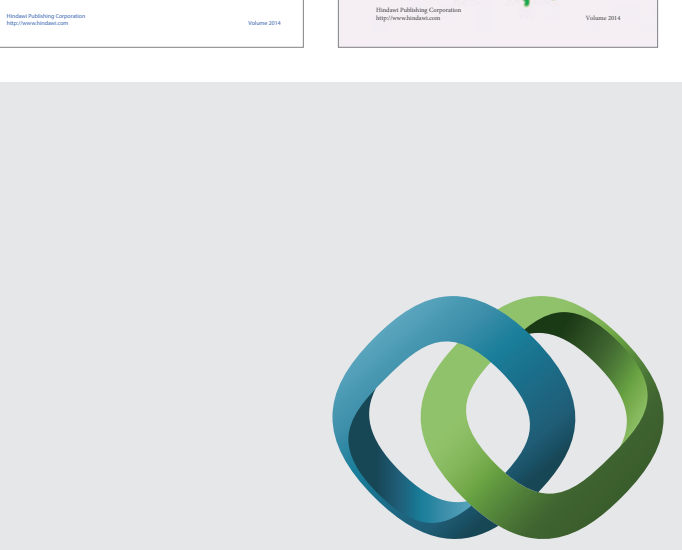

\section{Hindawi}

Submit your manuscripts at

http://www.hindawi.com
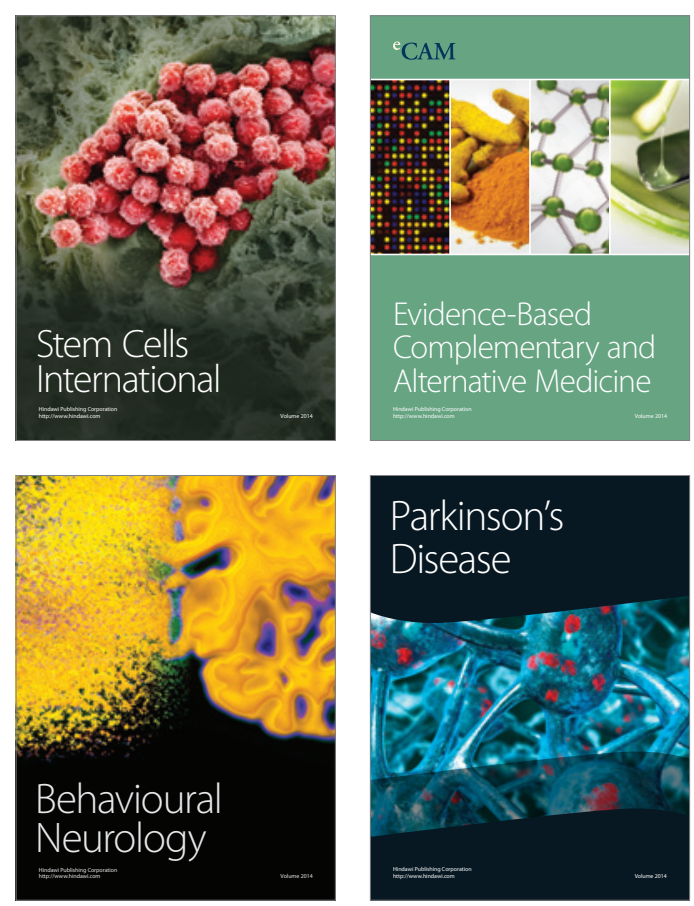

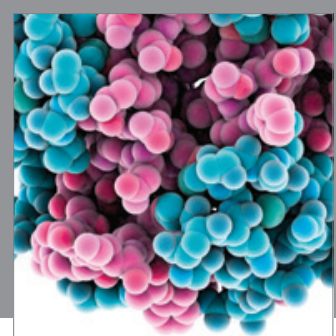

Journal of
Diabetes Research

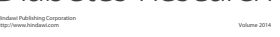

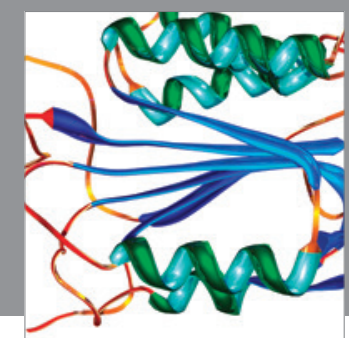

Disease Markers
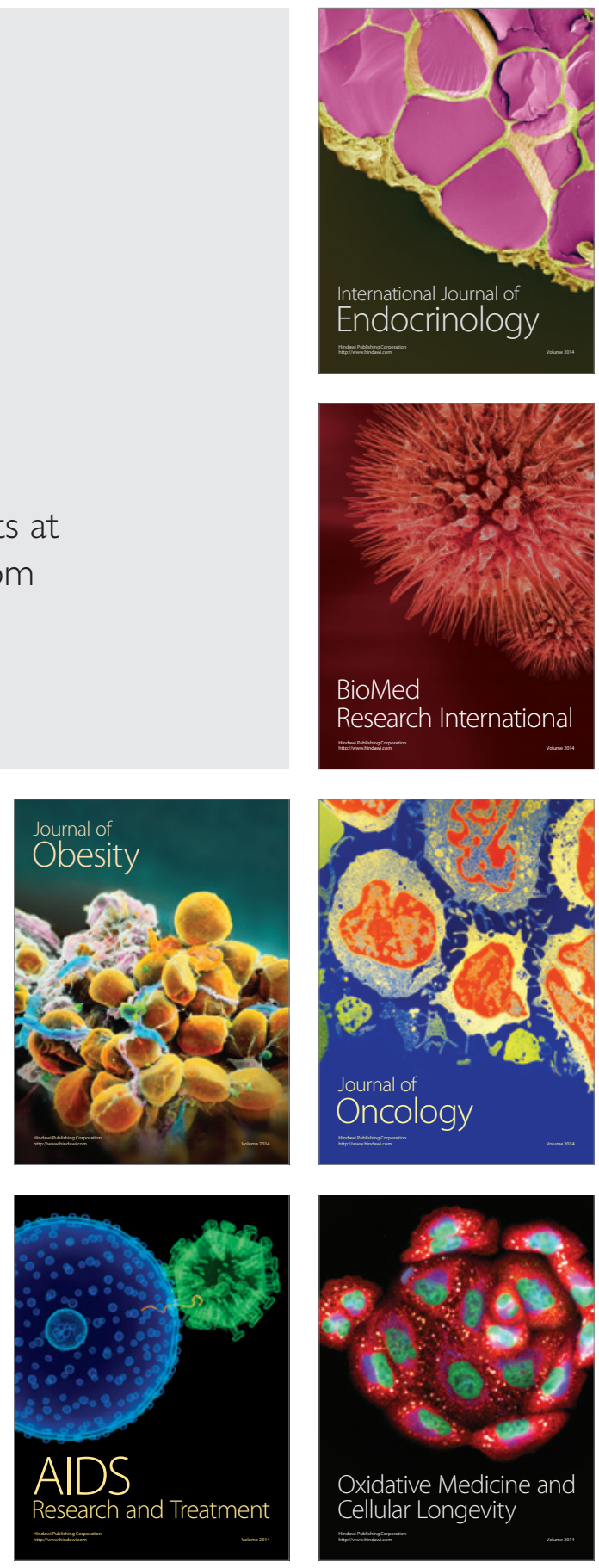